I N T ER N ATIONAL MONETARY FUND

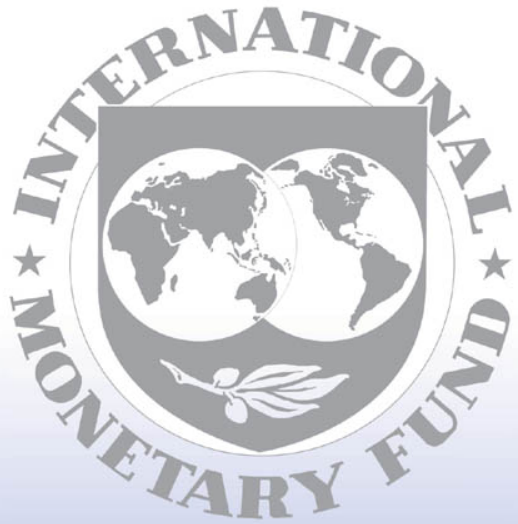

Staff

Country

Reports 


\section{British Virgin Islands - Overseas Territory of the United Kingdom: \\ Assessment of the Supervision and Regulation of the Financial Sector Volume I-Review of Financial Sector Regulation and Supervision}

This review of financial sector regulation and supervision in the British Virgin Islands in the context of the offshore financial center assessment program contains technical advice and recommendations given by the staff team of the International Monetary Fund in response to the authorities of the British Virgin Islands' request for technical assistance. It is based on the information available at the time it was completed in February 2004. The staff's detailed assessment of the observance of standards and codes can be found in Volume II. The views expressed in these documents are those of the staff team and do not necessarily reflect the views of the government of the British Virgin Islands or the Executive Board of the IMF.

The policy of publication of staff reports and other documents by the IMF allows for the deletion of market-sensitive information.

To assist the IMF in evaluating the publication policy, reader comments are invited and may be sent by e-mail to publicationpolicy@imf.org.

Copies of this report are available to the public from

International Monetary Fund • Publication Services

700 19th Street, N.W. • Washington, D.C. 20431

Telephone: (202) 6237430 • Telefax: (202) 6237201

E-mail: publications@imf.org • Internet: http://www.imf.org

Price: $\$ 15.00$ a copy

\section{International Monetary Fund Washington, D.C.}


ASSESSMENT OF THE SUPERVISION AND REgULATION OF THE FINANCIAL SECTOR

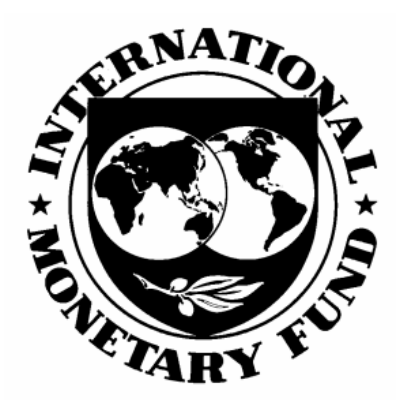

VOLUME I: Review of Financial Sector Regulation and Supervision

\section{British Virgin Islands}

FEBRUARY 2004 
The contents of this report constitute technical advice and recommendations given by the staff of the International Monetary Fund (IMF) to the authorities of a member country in response to their request for technical assistance. With the written authorization of the recipient country's authorities, this report (in whole or in part) or summaries thereof may be disclosed to IMF Executive Directors and their staff, and to technical assistance providers and donors outside the IMF. Disclosure of this report (in whole or in part) or summaries thereof to parties outside the IMF other than technical assistance providers and donors shall require the written authorization of the recipient country's authorities and the IMF's Monetary and Financial Systems Department. 
Glossary

Preface. $\underline{6}$

Executive Summary $\underline{8}$

I. Financial System and Offshore Overview …...................................................

A. Background $\underline{14}$

B. Financial Institutions and Markets $\frac{17}{20}$

C. Regulatory Framework, Oversight, and Market Integrity Arrangements $\underline{20}$

II. Strengths and Vulnerabilities in the Financial Regulatory and Supervisory Arrangements $\underline{25}$

A. Summary Assessment of Compliance with the Basel Core Principles for Effective Banking Supervision .$\underline{25}$

B. Summary Assessment of Implementation of the IOSCO Objectives and

Principles of Securities Regulation $\underline{32}$

C. Summary Assessment of Compliance with the International Association of Insurance Supervisors (IAIS) Insurance Core Principles $\underline{38}$

D. Summary Assessments of Compliance with the FATF Recommendations for Anti-Money Laundering and Combating the Financing of Terrorism.

III. Regulatory Arrangements of Particular Concern in the OFC Context

A. Oversight of Companies and Trusts Service Providers (CSP). .$\underline{51}$

B. Cross-Border Cooperation and Information Sharing

Tables

1. Summary of Findings, Follow-Up Action Plan, and Response of Authorities,

2. Including Possible TA Needs, Regarding Financial Sector Supervision...................11 .$\underline{53}$

3. Recommended Actions to Improve Implementation of the IOSCO Objectives and

Principles of Securities Regulation .......................................................... $\frac{36}{42}$

4. Recommended Action Plan......................................................................... $\frac{42}{49}$

5. Recommendations and Actions................................................................... 


\section{GLOSSARY}

AGC

AML

AMLCP

ARA

BTCA

$\mathrm{BCP}$

BIS

BVI

CA

CFT

CJIC

CMA

CSP

EU

FATF

FIA

FS(IC)A

FT

FCO

FSC

FSCA

FSD

GOB

GTL

IAE

IA

IR

IBCA

IOSCO

JAMLACC

KYC

MD

MFD*

MF Act

ML

MLAT

OECD

OFC

OGBS

Police FINU

PCCA
Attorney General's Chambers

Anti-Money Laundering

Anti-Money Laundering Code of Practice

Association of Registered Agents

Banks and Trust Companies Act, 1990

Basel Core Principle for Effective Banking Supervision

Bank for International Settlements

British Virgin Islands

Companies Act, 1885

Combating the Financing of Terrorism

The Criminal Justice (International Cooperation) Act

Companies Management Act, 1990

Companies and Trusts Service Providers

European Union

Financial Action Task Force

Financial Investigative Authority

Financial Services (International Cooperation) Act, 2000

Financing of Terrorism

Foreign and Commonwealth Office

Financial Services Commission

Financial Services Commission Act, 2001

Financial Services Department

Government-Owned Bank

General Trust License

Independent AML/CFT Expert

Insurance Act, 1994

Insurance Regulations, 1995

International Business Companies Act, 1984

International Organization of Securities Commissions

The Joint Anti-Money Laundering Coordinating Committee

Know Your Customer

Managing Director of the Financial Services Commission

Monetary and Financial Systems Department

Mutual Funds Act, 1996

Money Laundering

Mutual Legal Assistance Treaty

Organization for Economic Cooperation and Development

Offshore Financial Center

Offshore Group of Bank Supervisors

Police Financial Investigations Unit of the Royal Virgin Islands Police Force The Proceeds of Criminal Conduct Act 
RA Reporting Authority

RCA Registry of Corporate Affairs

STR Suspicious Transaction Report

*The IMF's Monetary and Exchange Affairs Department (MAE) was renamed the Monetary and Financial Systems Department (MFD) as of May 1, 2003. The new name has been used throughout the report. 


\section{Preface}

At the request of the authorities, an IMF team conducted a Module 2 Offshore Financial Center (OFC) assessment ${ }^{1}$ of the British Virgin Islands (BVI) during the period November 11-22, 2002. The mission undertook an assessment of the BVI's regulatory and supervisory arrangements with respect to internationally accepted standards and evolving good practices. The mission completed separate assessments of the BVI's observance of five standards and evolving good practices:

(1) The Basel Core Principles for Effective Banking Supervision (BCP);

(2) The Insurance Core Principles of the International Association of Insurance Supervisors (IAIS Insurance Core Principles);

(3) The Objectives and Principles of Securities Regulation of the International Organization of Securities Commissions (IOSCO Principles) (primarily with respect to the regulated mutual fund sector);

(4) The Methodology for Assessing Compliance with Anti-Money Laundering and Combating the Financing of Terrorism Standards (AML/CFT Methodology); ${ }^{2}$ and

(5) Good practices for company and trust service providers in the context of the September 6, 2002, draft statement of Best Practice of the Offshore Group of Banking Supervisors (OGBS Good Practices).

The assessment team consisted of Mr. Richard Gordon (Mission Chief, Monetary and Financial Systems Department); Ms. Pramita Moni Sengupta (Deputy Mission Chief, Legal Department); Mr. Joseph O’Neill (Banking Advisor); Mr. Tomas Power (Insurance Advisor); Ms. Tanis MacLaren (Securities Advisor); Mr. Hermann Krull (Company and Trust Services Advisor); and Ms. Marie-Christine Dupuis (AML/CFT Financial Sector Advisor), and Mr. Simon Quin (STA). Mr. Atle Roaldsøy, Norwegian Ministry of Justice, participated in the mission as an independent AML/CFT expert (IAE).

To conduct the assessments, the mission held discussions with the Governor of the BVI, the Honorable Chief Minister and Minister of Finance, senior management (including the Managing Director, Deputy Managing Director, and directors) and regulators of the BVI Financial Services Commission (FSC), the Attorney General of the BVI, the Financial

\footnotetext{
${ }^{1}$ The program of assessments is based on the paper presented to the IMF Board "Offshore Financial Centers - the Role of the IMF."

${ }^{2}$ As endorsed by the FATF in October 2002 and by the Fund's Executive Board in November 2002.
} 
Secretary of the BVI, the Commissioner of Royal Virgin Islands Police, and a very broad range of representatives of the financial services industry.

The team is very grateful for the cooperation and hospitality received from the BVI authorities and from private sector representatives. The team is especially grateful for the FSC's efforts in making all necessary logistical arrangements for the mission. 


\section{EXECUTIVE SUMMARY}

\section{Sectoral supervisory issues}

The BVI has most of the essential elements for a suitable framework for financial supervision. Primary legislation provides the FSC with adequate independence and authority to license and supervise covered financial services, which include banking, ${ }^{3}$ insurance, securities (mutual funds, their management, and investors), and trust and company service providers, whether onshore or offshore, and implementation has largely been good. In particular, the professionals who staff the FSC, led by senior management and directors, are dedicated and experienced professionals with a clearly articulated goal of maintaining and, where possible, improving the framework and implementation of financial services supervision in the BVI. While there are several weaknesses in the framework, the FSC and the BVI Government have indicated that they are keenly interested in addressing those weaknesses, and in many cases have already taken steps to that end.

While all indications are that the FSC acts in a fully independent and professional fashion, there are some changes to the FSCA that would further ensure that it continue to be independent and professional in the future, including with respect to selection of and term of the managing director, and the method of selecting board members.

There is a weakness with respect to onsite supervision of banking, insurance, and securities sectors. While there is often detailed and well-executed off-site inspection of relevant documents in the course of granting both initial licenses and license renewal (as well as on an ad hoc basis), there is currently no regular and comprehensive examination and compliance program in operation, and no on-site inspections of regulated entities/providers (regulated persons) other than trust and company service providers. However, the authorities, with KPMG's assistance, are implementing a comprehensive examination methodology and plan to start on site inspections in 2003. While there has been an increasing and dedicated effort to engage in consultations with industry, particularly with respect to education, this needs to be regularized and deepened, especially with respect to feedback from the regulated persons. Finally, in order to implement the proposed plan for on-site inspections, there is also a need to increase human resources, which the authorities are now undertaking with the help of, inter alia, international headhunting firms. In addition to these shortcomings that apply throughout all sectors, there are a number of issues specific to each of the banking, insurance, securities, and trust and company services provider sectors.

With respect to the banking sector, virtually all banks are subsidiaries or branches of high-quality banking institutions subject to effective consolidated supervision by the home country supervisor. However, there are few key weaknesses. While the FSC has requested that banks confirm that their policies and procedures are in compliance with relevant Bank

${ }^{3}$ The Development Bank is not subject to the FSC's authority. 
for International Settlements (BIS) papers, prudential standards such as guidance and parameters for assuming and managing risk have not been issued. The Government-Owned Bank (GOB), ${ }^{4}$ which operates in the local retail and commercial market, but which appears to have multiple weaknesses including high levels of nonperforming loans and outdated financial statements, is not currently under any outside prudential supervision, although this is planned to be introduced in 2003. In the past the FSC has in effect required an 8 percent risk-weighted capital requirement for subsidiaries (although such a requirement has been imposed as a matter of administrative discretion rather than by law or regulation) and the FSC imposed a 14 percent capital assignment for one of the three branches. A proposed amendment to the BTCA provides for a 12 percent risk-weighted capital requirement.

With respect to the insurance sector, all insurance companies insuring domestic risk are subsidiaries or branches of high-quality institutions subject to effective consolidated supervision, and most captives have single U.S.-based parents whose structure and operations have been vetted by the U.S. Internal Revenue Service., This, when combined with the FSC's supervision, has resulted in a well-supervised sector. However, a weakness can be found in a lack of guidelines for corporate governance and internal controls, which is of particular importance to supervision of managers of captives. Such guidelines are, however, planned to be introduced in early 2003. There is no compulsory errors and omissions, fidelity and surety and broad-form professional liability insurance for all providers, although this is also planned.

With respect to the securities sector, the FSC has generally done a good job of supervision. However, a few weaknesses include that the FSC needs to set out the prospectus disclosure requirements applicable for public funds, and generally the disclosure obligations of mutual funds need to be enhanced. In addition, business conduct rules and requirements for books and records, internal controls and risk management systems for mutual fund managers and administrators should be strengthened, and all managers, administrators and other mutual fund functionaries, such as custodians, should be required to segregate client assets effectively. Most of these issues, however, are addressed in a draft code of practice, expected to come into force in early 2004, while the remaining are expected to be addressed in proposed regulations for mutual funds.

With respect to international business companies the regime for registering and maintaining IBCs in the territory meets or exceeds most best practices; this is largely because IBCs have to be registered (incorporated) by registered agents who are themselves subject to regulation supervision (see below). A draft amendment to the (International Business Companies Act, 1984 (IBCA) is planned to require that the registered agents keep information on IBC directors in the territory. Amending legislation to the IBCA is currently being finalized to implement the immobilization of bearer shares. This requirement appears

\footnotetext{
${ }^{4}$ The Development Bank of the Virgin Islands.
} 
to satisfy concerns of the Financial Action Task Force (FATF) and (Organization for Economic Cooperation and Development) OECD, among others.

With respect to the trust and company services provider sector, all CSPs are subject to regulation and supervision by the FSC. Such oversight largely meets industry best practices as provided in the OGBS Statement of Best Practices. However, particularly in view of very large IBC client base and, in particular, the need to assess compliance with the OGBS statement of best practice (including that action can be taken where there is evidence of noncompliance); there is a need to complete inspections of all CSPs, and to draft a regular compliance and on-site inspection program. Also, inspections could be more detailed and structured. Greater contact and consultation by the FSC and the BVI Association of Registered Agents would also be helpful.

\section{Framework for anti-money laundering/combating the financing of terrorism}

The legal framework for AML/CFT measures in the BVI is generally compliant with international standards. Sufficient legal means and measures are in place for criminalization of (money laundering) ML and (financing of terrorism) FT, to facilitate international cooperation in ML and FT matters, and to provide for confiscation and forfeiture of assets associated with ML and FT. Although the Attorney General's Chambers (AGC) appear to be well versed to handle complex matters, few prosecutions have taken place in the BVI, and any increase in the number of prosecutions would impose a heavy burden on the AGC's Commercial Crimes Unit. Required measures for FT, including criminalization and freezing/confiscation of FT assets have been fully integrated into the legal framework. The BVI has taken a pragmatic approach to establishing the supervisory framework for AML/CFT measures and applying due diligence requirements to all regulated persons. Money remitters are not yet subject to licensing or prudential supervision, although this is contemplated under a proposed law, which authorities expect to be enacted in the first half of 2003. The FSC is carefully building its staff to cover the range of its mandates, by enhancing the staff for AML/CFT compliance, including filling vacancies in the Legal and Enforcement Division; such staff will have a significant role in implementing the legal and supervisory framework under the AMLCP and the guidance notes.

While the legal and supervisory frameworks are adequately structured, the implementation of the full range of AML/CFT supervisory measures has not yet been fully achieved.

Verification of AML/CFT must be an essential part of these examination procedures and manuals. Specific file review and transaction testing are also needed as the supervisory measures are implemented. Nevertheless, the mission notes significant progress in the FSC's development of necessary supervisory measures the supervisors have kept abreast of the concerns of the financial sector and have provided extensive training and guidance to the financial intermediaries to aid in establishing adequate internal compliance measures.

\section{Cross-border information exchange and cooperation}

Cross-border information exchange and cooperation has been excellent in all areas. 
Table 1. Summary of Findings, Follow-Up Action Plan, and Response of Authorities, Including Possible TA Needs, Regarding Financial Sector Supervision ${ }^{5}$

\begin{tabular}{|c|c|c|}
\hline \multicolumn{3}{|c|}{ Issues of General Applicability } \\
\hline Findings & Action Plan & $\begin{array}{l}\text { Response of Authorities and } \\
\text { Follow Up TA Needs }\end{array}$ \\
\hline $\begin{array}{l}\text { Executive Council not required to } \\
\text { disclose grounds for removal of } \\
\text { board members. }\end{array}$ & $\begin{array}{l}\text { Amend FSCA to require executive } \\
\text { council to disclose grounds for } \\
\text { removal. }\end{array}$ & FSC Board to consider. \\
\hline $\begin{array}{l}\text { Conflicts policy for FSC board } \\
\text { members could be made more } \\
\text { detailed and specific. }\end{array}$ & Amend board Code of Conduct. & $\begin{array}{l}\text { FSC Board to consider amending } \\
\text { Code of Conduct. }\end{array}$ \\
\hline $\begin{array}{l}\text { MD does not have fixed-term } \\
\text { appointment. } \\
\text { FSC board not required to disclose } \\
\text { grounds for removal. }\end{array}$ & $\begin{array}{l}\text { Amend FSCA to provide for fixed-term } \\
\text { appointment and disclosure of grounds } \\
\text { for dismissal. }\end{array}$ & FSC Board to consider. \\
\hline $\begin{array}{l}\text { Vacancies in directorships of Legal } \\
\text { Department, Policy Planning } \\
\text { Department, anticipated vacancies in } \\
\text { at least one other department. }\end{array}$ & Fill vacancies. & $\begin{array}{l}\text { Legal Department vacancy filled, } \\
\text { search for head of Policy Planning in } \\
\text { effect using international } \\
\text { headhunters. }\end{array}$ \\
\hline $\begin{array}{l}\text { Need for additional trained } \\
\text { regulatory staff. }\end{array}$ & $\begin{array}{l}\text { Recruit additional regulatory staff for } \\
\text { each directorate. }\end{array}$ & Recruitment in process. \\
\hline $\begin{array}{l}\text { Specialized consultants and/or } \\
\text { requiring external auditors not used } \\
\text { to perform and certify certain } \\
\text { compliance testing. }\end{array}$ & $\begin{array}{l}\text { Provide training of new staff. } \\
\text { Consider using consultants. }\end{array}$ & Training plan drafted. \\
\hline $\begin{array}{l}\text { Detailed reasons for all non-routine } \\
\text { decisions not always provided unless } \\
\text { requested. }\end{array}$ & $\begin{array}{l}\text { Amend guidelines to require that } \\
\text { reasons for all non-routine decisions be } \\
\text { provided. }\end{array}$ & $\begin{array}{l}\text { FSC board to consider amending } \\
\text { guidelines. }\end{array}$ \\
\hline $\begin{array}{l}\text { No regular and comprehensive audit } \\
\text { and compliance program. } \\
\text { No on-site inspections. }\end{array}$ & $\begin{array}{l}\text { Prepare plan and procedures for audit } \\
\text { and compliance program. } \\
\text { Begin on-site inspections. }\end{array}$ & $\begin{array}{l}\text { Training for KPMG's computer } \\
\text { based on-site inspection program was } \\
\text { recently completed for } \\
\text { implementation } 1^{\text {st }} \text { quarter } 2004 \text {. }\end{array}$ \\
\hline No manual for inspections. & $\begin{array}{l}\text { Complete manuals. } \\
\text { Train staff. }\end{array}$ & $\begin{array}{l}\text { On-site inspections to begin } 1^{\text {st }} \\
\text { quarter } 2004 \text {. } \\
\text { Computer based procedures manual } \\
\text { completed by KPMG. } \\
\text { Job description questionnaire for } \\
\text { inspection coordinator completed } \\
\text { with vacancy to be filled shortly } \\
\text { using international headhunters. }\end{array}$ \\
\hline
\end{tabular}

${ }^{5} \mathrm{~A}$ summary of findings for AML/CFT is reported separately below. 


\begin{tabular}{|c|c|c|}
\hline & & $\begin{array}{l}\text { Technical assistance in conducting } \\
\text { inspections and in related capacity- } \\
\text { building programs. }\end{array}$ \\
\hline $\begin{array}{l}\text { Accounting standards for financial } \\
\text { statements not detailed; allowed to } \\
\text { use home jurisdiction standards. }\end{array}$ & $\begin{array}{l}\text { Clarify the accepted accounting } \\
\text { standards based on International } \\
\text { Accounting Standards (IAS) or a } \\
\text { combination of IAS and U.S. GAAP. }\end{array}$ & Draft legislation pending. \\
\hline \multicolumn{3}{|c|}{ Summary of Issues Relevant to the Banking Sector } \\
\hline Findings & Action Plan & Follow Up/TA Needs \\
\hline $\begin{array}{l}\text { GOB not subject to the prudential } \\
\text { supervision of the FSC. }\end{array}$ & $\begin{array}{l}\text { Amend legislation to subject GOB to } \\
\text { supervision by FSC. }\end{array}$ & Draft legislation pending. \\
\hline $\begin{array}{l}\text { No risk based capital requirement in } \\
\text { law or regulations for subsidiaries. } \\
\text { No capital allocation for branches. }\end{array}$ & $\begin{array}{l}\text { Consider issuing regulation } \\
\text { establishing adequate capital } \\
\text { requirements consistent with } \\
\text { international standards. }\end{array}$ & $\begin{array}{l}\text { Draft legislation that includes } \\
\text { requiring a } 12 \text { percent risk based } \\
\text { capital pending. } \\
\text { Branches will be required to have an } \\
\text { assignment of capital by Q2 } 2004\end{array}$ \\
\hline $\begin{array}{l}\text { No specific prudential regulations on } \\
\text { credit concentration, credit reserve } \\
\text { requirements, connected lending, } \\
\text { liquidity requirements, and country } \\
\text { risk limitations. }\end{array}$ & $\begin{array}{l}\text { Consider prudential regulations based } \\
\text { on internationally recommended } \\
\text { standards tailored to the local } \\
\text { circumstances, discuss with banks; } \\
\text { promulgate appropriate standards. }\end{array}$ & $\begin{array}{l}\text { The FSC has drafted Large Exposure, } \\
\text { Liquidity Policy and a Code of } \\
\text { Banking Practice to be adopted by } \\
\text { Q1 } 2004 .\end{array}$ \\
\hline $\begin{array}{l}\text { The FSC requires audited financial } \\
\text { statement of the subsidiaries, but not } \\
\text { of branches. }\end{array}$ & $\begin{array}{l}\text { Amend guidelines to require audited } \\
\text { financial statement of branches. }\end{array}$ & $\begin{array}{l}\text { Branches are now required to submit } \\
\text { audited financial statements. }\end{array}$ \\
\hline \multicolumn{3}{|c|}{ Issues Relevant to the Insurance Sector } \\
\hline Findings & Action Plan & Follow Up/TA Needs \\
\hline $\begin{array}{l}\text { Lack of guidelines on the operations } \\
\text { of insurance managers and other } \\
\text { intermediaries on corporate } \\
\text { governance and internal control } \\
\text { procedures. }\end{array}$ & $\begin{array}{l}\text { Assess the suitability of applicable } \\
\text { IAIS Guidance notes; discuss with } \\
\text { intermediaries and other stakeholders; } \\
\text { promulgate appropriate standards. }\end{array}$ & In process, to be completed in 2003 . \\
\hline $\begin{array}{l}\text { Errors and Omissions, Fidelity and } \\
\text { Surety and Professional Liability } \\
\text { insurance not required for all } \\
\text { insurance managers, compliance } \\
\text { officers and insurance agents and } \\
\text { brokers based on a sliding scale of } \\
\text { level of exposure to various hazards. }\end{array}$ & $\begin{array}{l}\text { Determine appropriate types of } \\
\text { insurance necessary; discuss with } \\
\text { industry; assess appropriate levels of } \\
\text { exposure; issue guidance requiring } \\
\text { coverage. }\end{array}$ & In process, to be completed in 2003. \\
\hline \multicolumn{3}{|c|}{ Issues Relevant to the Securities Sector } \\
\hline Findings & Action Plan & Follow Up/TA Needs \\
\hline $\begin{array}{l}\text { Mutual fund conflicts of interest not } \\
\text { dealt with comprehensively. }\end{array}$ & $\begin{array}{l}\text { Issue formal requirement (under either } \\
\text { the prospectus requirements in } \\
\text { proposed public mutual funds } \\
\text { regulations or in draft Code of Practice) } \\
\text { for disclosure of all of the relationships } \\
\text { between the managers, administrators, } \\
\text { other functionaries and service } \\
\text { providers. }\end{array}$ & $\begin{array}{l}\text { To be included in proposed public } \\
\text { mutual funds regulations (end of Q2 } \\
\text { 2004) and draft Code of Practice (end } \\
\text { of Q1 2004). }\end{array}$ \\
\hline
\end{tabular}




\begin{abstract}
No requirement of mutual funds, managers and administrators to file annual audited financial statements with the FSC, or of managers and administrators should also be required to file other regulatory reports.
\end{abstract}

No specific requirements regarding books and records, or that assets be segregated.

No guidelines for issuing

prospectuses of public mutual funds.

Requirement for public mutual funds to make immediate disclosure of any material changes to be expanded.

No rules on public mutual fund asset valuations and related disclosure provisions.

No prohibition on public mutual funds from ceasing to redeem its securities without the permission of the FSC.

\begin{tabular}{|l|l|l|}
\hline \multicolumn{2}{|c|}{ Issues Relevant to the IBC and Trust and Company Service Provider Sectors } \\
\hline \multicolumn{1}{|c|}{ Findings } & \multicolumn{1}{c|}{ Action Plan } & \multicolumn{1}{c|}{ Follow Up/TA Needs } \\
\hline $\begin{array}{l}\text { Ensure continuing and enhanced } \\
\text { compliance with current draft of } \\
\text { OGBS Statement of Best Practice. }\end{array}$ & $\begin{array}{l}\text { Monitor and measure Bank \& } \\
\text { Fiduciary Services Division policies } \\
\text { and implementation against OGBS } \\
\text { Draft Methodology Document. }\end{array}$ & $\begin{array}{l}\text { After finalization and acceptance of } \\
\text { OGBS Draft Methodology } \\
\text { Document, follow-up audit to be } \\
\text { undertaken by MFD of the Division's } \\
\text { findings }\end{array}$ \\
\hline $\begin{array}{l}\text { More detailed and structured on-site } \\
\text { inspection of CSPs needed to be able } \\
\text { to take action where there may be } \\
\text { evidence of noncompliance. }\end{array}$ & $\begin{array}{l}\text { Introduce a staff secondment program } \\
\text { with the local CSP industry and } \\
\text { auditing firms. }\end{array}$ & $\begin{array}{l}\text { FSC to liaise with the local CSP } \\
\text { industry and auditing firms }\end{array}$ \\
\hline $\begin{array}{l}\text { Increased input form industry needed } \\
\text { in respect of supervisory processes. }\end{array}$ & $\begin{array}{l}\text { Increase contact and consultation with } \\
\text { the BVI Association of Registered } \\
\text { Agents. }\end{array}$ & $\begin{array}{l}\text { FSC to establish a closer working } \\
\text { implemented Q1 2004 } \\
\text { relationship with the Association of } \\
\text { Registered Agents by Q1 2004. }\end{array}$ \\
\hline
\end{tabular}

Issue guidelines in draft Code of Practice and Mutual Funds Amendment Act. requiring filing annual audited financial statements, including regular inspections.

Except for custodians and others over whom the FSC has no jurisdiction, issue detailed guidelines on keeping of books and records and on asset segregation applying to all functionaries who hold BVI registered public mutual fund assets.

Issue guidelines in the proposed Public Funds Regulations and Mutual Funds Amendment Act regarding prospectuses for public mutual funds.
To be included in draft Code of Practice (end of Q1 2004) and Mutual Funds Amendment Act (end of Q4 2003)

To be included in proposed public mutual funds regulations (end of Q2 2004) and draft Code of Practice (end

To be included in proposed public mutual funds regulations (end of Q2 2004) and Mutual Funds Amendment Act (end of Q4 2003). of Q1 2004).
Issue guidelines in the draft Code of Practice on asset valuations and related disclosure provisions.

Issue guidelines in the proposed public mutual funds regulations requiring public mutual funds to notify the FSC before ceasing to redeem its securities.
To be included in the draft Code of Practice (end of Q1 2004).

To be included in proposed public mutual funds regulations (end of Q2 2004). 


\section{FinANCIAL SYSTEM AND OFFSHORE OVERVIEW}

\section{A. Background}

\section{Setting}

1. The BVI is a British Overseas Territory of 153 square kilometers in size and comprising over 40 islands, islets and cays, with a population of around 21,000. About two-thirds of the population lives on the island of Tortola (53 square kilometers) and another 15 percent on the island of Virgin Gorda (21 square kilometers), with the remainder on a few of the other larger islands. The BVI's annual per capita income is about $\$ 37,000$ and the median income about $\$ 11,000$ (although the cost of living is high). While the territory has virtually no unemployment and a relatively high level of other social indicators, some small pockets of relative poverty do remain. The BVI is highly dependent on both tourism and the offshore financial sector (both approximately 40 to 45 percent of GDP), although exact figures are difficult to estimate. However, it is these sectors on which the future prosperity of the territory is likely to depend.

2. The BVI is subject to a number of constraints on the development of its economy. The BVI is a small jurisdiction with a limited stock of office and hotel space (including convention facilities) and has a relatively small airport that cannot accommodate wide-body planes. These limitations are due in part to the physical nature of the islands, which are small, mostly volcanic, and extremely steep, thereby limiting the amount of land suitable for construction of new or improved facilities. The government has also adopted policies designed to preserve the charm, beauty, and environmental quality of the islands, including size and number restrictions on new construction. This lack of suitable office and hotel space has constrained the development of both the tourism and financial services sector. In addition, the relatively small population, the lack of superior onshore secondary education facilities, and labor and immigration laws have contributed to a relative dearth of available human capital, especially with respect to sophisticated financial services. Currently, approximately 40 percent of the labor force comes from outside the territory.

\section{Government}

3. The BVI enjoys a large measure of self-government as an internally-governing overseas territory of the U.K. The governor, who is appointed by the U.K. Foreign and Commonwealth Office (FCO), retains direct responsibility for external affairs, the terms and conditions of public service, and the administration of justice, including the police and the courts. He also appoints the (nonpolitical) attorney general, who typically comes from outside the Islands. All other executive functions are exercised by the executive council, which consists of the chief minister (analogous to the U.K. prime minister) and four other ministers, all of whom are elected members of the legislative council, and the attorney general (ex officio). The governor normally chairs sessions of the council. The legislative council consists of 13 members elected for a term not exceeding four years. The judicial branch includes a high court with two resident judges and a single magistrate. The appeal 
court and high court are associated with the Organization of Eastern Caribbean States (OECS).

4. A well-compensated professional civil service operates the various government departments in the U.K.-style, and generally has a high reputation, although there is a need for additional human resources in many cases. In addition, there are also a number of statutory bodies with authority independent of the ministries, including the Tourist board and the FSC, which hire their own staff and which, while not subject to the same civil service rules, are also well compensated and generally maintain a high reputation. In particular, the administration of justice, including AGC, police, and courts, is a key element in minimizing reputational risk, and all have excellent reputations both within and without the territory.

5. Overall, BVI governance has generally been quite good. The presence of a governor largely beyond local political influence, who is both privy to all executive council deliberations and who directly oversees the terms and conditions of public service and the administration of justice appears to have a beneficial effect on the territory's reputation for probity. The recent AGC prosecution of the former financial secretary for corruption related to the recent airport expansion indicates that the various checks and balances are robust.

\section{Overview of financial services}

6. Commensurate with its small population, the BVI has a small domestic market for financial services. As a general matter, there are no separate regulatory schemes for financial services offered to the domestic market and those restricted to nonresidents ("offshore"), although there is for company registration (see below). There is a very limited offshore banking sector, which is insignificant when compared to well-developed offshore centers. The BVI has made a policy determination of only allowing highly reputable institutions subject to effective consolidated supervision to engage in onshore or offshore banking. The offshore insurance sector is restricted to captive insurers and to their managers. The offshore securities sector is limited to mutual funds, their managers, and administrators.

7. By far, the largest offshore activity is the registration of IBCs. The IBCA, which was enacted in 1984, sets out a separate corporate regime for IBCs, which are prohibited from carrying on business with BVI residents or of owning real property in the BVI, although BVI residents may hold shares or other securities in the IBC. In exchange, IBCs are exempt from certain duties of domestic companies, including, inter alia, holding annual shareholders meetings, publicly maintaining certain records (including a registry of shareholders) and paying income, stamp, or other taxes. The BVI was the only Caribbean Oversees Territory identified by the European Union (EU) as not conforming with its Code of Conduct on Business Taxation because of the ring-fencing nature of the IBC tax regime. For this reason, the chief minister recently stated that the government would combine the IBCA and the Companies Act, 1885 (CA into a single law by end-2003, and move to a zero rate of income tax by 2005 . 
8. Low registration and license fees, coupled with an exceptionally efficient registration system and low reputational risk contributed to the significant growth of this sector. In 1989, the government sent a delegation to Hong Kong, then a British Crown Colony, to promote the use of IBCs to hold assets in anticipation of the 1997 return of the colony to Chinese sovereignty. This visit was followed by a significant increase in the registration of IBCs by Hong Kong residents, and it is estimated that a significant number of IBCs continue to be formed by residents of Hong Kong, now a Special Administrative Region of China. The FSC and the private sector estimate that there are approximately 350,000 active IBCs registered in the BVI, which is assumed to dominate the world IBC market with an estimated 45 percent share. The IBCs are also used as vehicles for captive insurance companies and for mutual funds. The large number of IBCs incorporated in the BVI makes the importance of effective AML/CFT policies at the company service provider sector particularly important.

9. Under the IBCA, an IBC must be incorporated by and, at all times, maintain a registered agent. Registered agents are subjected to prudential licensing and supervision requirements and to AML/CFT duties. While incorporation duties provide the bulk of fees for registered agents, they also provide other services, such as IBC directors and nominee shareholders. In addition, those with general licenses may provide trustee services and other trust management services.

10. In recent years, the number of IBCs being registered has begun to level off or even decline, while the number of companies being struck from the register (typically due to nonpayment of license fees or, less commonly, formal winding-up) has increased. This appears to be a worldwide trend, due in part to increased regulatory and AML/CFT standards, as well as to the fact that a title to a significant percentage of personal wealth has already been transferred to IBCs. This has led to concerns on the part of the registered agent community, and an even greater interest in moving beyond what has largely been the "commodity" production of registering companies, toward the provision of more sophisticated (and higher value added) financial services. However, this effort has been hampered by a number of causes, the most important being a lack of sophisticated international banking services and of qualified personnel. The government has begun to look into how these problems can be rectified without sacrificing the quality of life in the territory.

\section{Budgetary considerations}

11. The BVI Government revenues are dependent on the offshore sector and, in particular, on fees for the registration and licensing of IBCs. Last year, these fees accounted for approximately 55 percent of total government revenues of US\$187,476,000. Other key sources of revenue include personal and corporate income tax at 17 percent, and import duties at 10 percent of total revenues. As noted, revenues from registration and licensing of IBCs are expected to remain relatively flat, and the chief minister has announced that, to eliminate the ring fencing nature of the IBC regime, the government intends to move to a zero rate of income tax by 2005 . Finally, import duties are relatively inelastic due to the small retail sector and the common practice of individuals of bringing in goods duty free 
from the U.S. Virgin Islands and Puerto Rico, and to the large number of politically popular exemptions, particularly certain nonprofit entities.

12. Government expenditures, however, are expected to continue to rise. The BVI's recurring revenues have traditionally run a surplus of a few percentage points over recurring expenditure, and capital projects have traditionally been funded from this surplus and from sources like the Caribbean Development Bank and the European Investment Bank. Currently, public debt stands at around US\$46 million or less than 25 percent of annual government revenues, and government guaranteed debt of state-owned enterprises and others at a more or less equal amount. ${ }^{6}$ However, two new and costly capital projects have been approved recently by the legislative council, an 80-bed hospital and a new sewage treatment plant. Together, these projects are estimated to cost around US\$160 million, to be financed primarily through additional borrowing. The costs of these projects are expected to create additional pressure on the budget.

13. Even if the government does not go ahead with its current plans to eliminate the income tax, the expected flattening and even reduction of registration and license fees from IBCs, plus the increase in debt service costs from the new capital projects, is expected to result in a tight budgetary situation for the foreseeable future.

\section{B. Financial Institutions and Markets ${ }^{7}$}

\section{Banks}

14. The banking sector of the BVI is quite small—composed of 11 banks: 6 general, 4 restricted licensees, and 1 state-owned bank. The general license banks are authorized to engage in banking business within and outside the BVI. The restricted license banks may only engage in banking business outside the BVI, with certain exceptions. All banks (other than GOB bank) of any significance are subsidiaries or branches of foreign banking groups.

15. The GOB was created with a special mandate to promote the development of the BVI. The GOB is authorized to accept local deposits and engages primarily in lending to the consumer, mortgage, and small business, tourism, and government sectors.

\section{Insurance}

16. The local insurance market is relatively small, at about US $\$ 40$ million in annual premium. The 30 firms licensed to write direct insurance on personal and commercial risk in the territory are primarily well-established firms that are well regulated in their home

\footnotetext{
${ }^{6}$ Public borrowing must first be approved by the FCO.

${ }^{7}$ Unless otherwise stated, data is as of end-September 2002.
} 
jurisdictions. There are also 13 licensed insurance agents, 11 licensed insurance brokers, and 7 loss adjusters. The market appears to be stable.

17. The BVI is a major and growing market for captive insurers, which number 263, approximately 95 percent of which are single-parent captives, and all but 22 of which are organized to insure U.S.-based risks, and have been certified by the United States Internal Revenue Service under applicable U.S. tax laws. This represents about 9 to 10 percent of the world market for captive insurers. None is allowed to underwrite third-party insurance on a direct basis. The insurance premia of the single-parents' captives is typically under US\$500,000 (due to the exemption requirements of the U.S. Risk Retention Act). A small percentage of the captives have an in-house business in property casualty with premia that exceeds US\$1 million. While statistics are not kept, it is estimated that captive premia for 2002 will exceed US $\$ 400$ million. The sector is growing at a rate of about 10 percent per year.

18. There are also 12 licensed insurance managers who manage the captives and who act as agents and all of which are required to have physical presence in the territory; most of the captive business is managed by subsidiaries of large and well established multinationals.

\section{Securities (mutual funds)}

19. There is no stock exchange in the BVI, nor is there any facility for the issue of securities other than mutual funds. There is no retail market for securities of any kind in the jurisdiction.

20. The BVI is a major jurisdiction for the incorporation of mutual funds. A total of 2,606 mutual funds had been registered or recognized in the BVI. The rate of growth of funds is over 14 percent per year. About 8 percent of the total number of funds is public mutual funds that may be sold by prospectus to any investor. The rest are either professional funds (sold to sophisticated purchasers only) or private funds, where offers to the public are prohibited and the number of investors must be fewer than 50. The BVI regulator does not collect data on the size of mutual funds authorized in the jurisdiction, but estimates the total assets of all public, private, and professional funds under management as exceeding US\$55 billion. However, with the advent of the FSC's planned Policy, Research, and Statistics Division, the collection of such data would be possible.

21. Around 490 licenses for mutual fund administrators and managers have been granted (this number does not reflect cancellations). There has been a growth in the granting of licenses of nearly 20 percent per year. Very few of the licensed managers or administrators are physically located in the territory. Mutual funds are not required to have managers or administrators that are licensed by the FSC. The BVI legislation presently does not give the FSC the authority to regulate other market participants (e.g., portfolio dealers or underwriters) and there is no data on the size and operations of these other participants. However, the draft Investment Business Act would do so. 


\section{IBCs and trust and company service providers}

22. The FSC and industry representatives estimate that there are around 350,000 IBCs in the BVI, which represents around 45 percent of the total world market. Most IBCs appear to be used as holding companies for shares, trust property, and other assets, while a smaller but still significant number appear to be used for private investment activity. On balance, the IBCs client base tends to come from the Far East, Europe, and Latin America.

23. All IBCs must be registered in the BVI by a registered agent and, at all times, the IBCs must have an office maintained in the British Virgin Islands by the company or its registered agent, and have a registered agent at all times. Therefore, the registered agent is the key to the registration of IBCs and to any information about IBCs not included in registration documents.

24. Registered agents can be licensed either under the Companies Management Act, 1990 (CMA) or the Banks and Trust Companies Act, 1990 (BTCA) to carry on the business of company management, defined as the registration of companies under the CA or the IBCA, the provision of registered agent services for companies incorporated under the IBCA, the provision of registered office services for companies incorporated under the CA or the IBCA. However, this also includes the provision of directors or officers for companies, and the provision of nominee shareholders of companies. All registered agents are required to establish a physical presence in the BVI at the time of licensing.

25. Also, a registered agent who is licensed under the BTCA is also automatically licensed to conduct trust business, which is defined as acting as a professional trustee, protector, or administrator of a trust or settlement; managing or administering any trust or settlement; and company management as defined in the CM Act.

26. A license to conduct trust business is referred to as a General Trust License (GTL). Not all GTL holders are registered agents, however. The holder of a Restricted Trust License may not conduct the business of company management, and can therefore not be a registered agent. In addition, it may only act as a professional trustee, protector, or administrator of a trust or settlement, and manage or administer any trust or settlement (i.e., trust business as defined, excluding company management), up to a maximum of 25 trusts (proposed to be increased to 50), all of which have to be listed in the original license application. Any addition or change to the list of trusts in the original license application requires a new application, and a subsequent reassessment of the applicant is undertaken.

27. All licenses are valid until December 31 of the year in which they are issued, and are renewable during January of the next year. Currently, there are 20 licenses for Company Management Services under the CMA; 96 licenses for Restricted Trust Business under the BTCA; and 92 licenses for General Trust Business under the BTCA. Forty-nine of the 92 General Trust Business license holders, and 20 subsidiaries of General Trust Business license holders, have also been registered as registered agents, bringing the total number of registered agents (including the 20 licenses under the CMA) to 89. 
28. No CSP is a provider of banking, accounting, or legal services, but a number of them have connected-entity relationships with law firms, banks, and accounting or other financial service firms. All CSPs are required to maintain a principal office in the BVI.

\section{Regulatory Framework, Oversight, and Market Integrity Arrangements ${ }^{8}$}

\section{Legal structure}

29. The Financial Services Commission Act (FSCA), which came into effect in January 2002, establishes the Financial Services Commission (FSC) as an independent statutory body.

30. The FSC has responsibility and authority to grant and revoke licenses of all covered financial services, including banking, insurance, securities, and trust and company service provider sectors, whether onshore or offshore, and to supervise the operations of such persons. ${ }^{9}$ The FSC also has responsibility for registering domestic companies, IBCs, and limited partnerships, and for overseeing compliance of those companies with the terms of the $\mathrm{CA}$ and the IBCA. Other functions of the FSC include monitoring, detecting, and assisting in the prosecution of financial crime, maintaining contact with foreign regulators, public education, and advising the executive council on needed changes in legislation. There is also a provision for an independent appeals board with jurisdiction to consider appeals of any FSC action except the refusal to grant a license.

31. The FSCA was enacted in response to a key recommendation of the Review of Financial Regulation in the Caribbean Overseas Territories and Bermuda prepared by KPMG (KPMG Report) that the BVI's existing regulatory framework, which included the then main licensing and supervisory authority, the financial services department (FSD) of the finance ministry, be turned into an independent regulatory body, and that other powers relating to licensing and supervision exercised by the governor in council, the ministry of finance, and individual regulators, be transferred to the new independent body. Also following the recommendations of the KPMG Report, the promotional duties previously performed by the FSD were transferred to a new financial services marketing unit within the BVI Government.

32. The FSCA (as supplemented by other authority found in sector-specific laws and regulations) provides the FSC with a broad arsenal of specific regulatory, supervisory, and enforcement powers. These include the powers to:

\footnotetext{
${ }^{8}$ See Appendix 1 for a detailed description of the FSC.

${ }^{9}$ Plans are to bring the GOB under the FSC's authority; previously it had been assumed that the presence of government appointed directors rendered unnecessary the need for additional supervision.
} 
- $\quad$ issue, with the approval of the executive council, necessary regulations for the conduct of regulated persons and officers, and agents of regulated persons;

- $\quad$ prescribe manuals of compliance procedures and codes of practice for regulated persons;

- $\quad$ require that every regulated person should appoint compliance officers and further describe the compliance officers' responsibilities and functions;

- $\quad$ require persons engaged in financial services business (or other connected persons) to furnish any relevant information (that is not a privileged communication) needed for the discharge of the FSC's functions, including applying for, and executing, search warrants;

- $\quad$ conduct compliance inspections of regulated persons;

- $\quad$ appoint investigating examiners, appoint advisers, issue cease-and-desist directives, revoke or suspend authorizations, to apply to the court for orders to protect the businesses or property of regulated persons;

- $\quad$ compound offenses under the act;

- to provide any information it has or is otherwise entitled to have to:

- any high-ranking officer in an international organization or law enforcement authority in a jurisdiction approved by the board; and

- any foreign regulatory authority in a jurisdiction approved by the board that discharges duties or has existing powers corresponding to those of the FSC.

\section{Books of account and budgetary issues}

33. While the FSC is required to keep audited books of account, which, along with a report on its activities, must be tabled before the executive and legislative councils, such books and reports have not yet been prepared, since the FSC has only recently begun operation. The FSCA also provides for basic obligations on conflicts of interest, confidentiality, etc. These have been supplemented by additional rules and procedures adopted by the board. However, the rules on conflicts of interests could be made more specific.

34. While the FSC has been provided a quasi-independent source of funding based primarily on a percentage of receipts of registration and license fees, the actual amount it is allowed to keep (not less than 7.5 percent or the previous year's allocation, and normally not more than 15 percent) is based on a negotiated agreement between the executive council and the FSC. The FSC currently estimates that it requires at least 10 percent of such fees which, given its current resource demands, especially for regulatory staffing, is conservative. It is 
not yet clear if this level of funding will be achieved by negotiation; if not, the minimum threshold of 7.5 percent would be instituted. However, the general budgetary squeeze anticipated over the next few years, plus the place of registration and licensing fees as the main source of government revenue may result in additional pressures on this process in future. This could result in resource constraints for the FSC.

\section{Board of Commissioners}

35. The Board of Commissioners is non-executive, with its activities limited to creating and appointing senior management (except for the managing director (MD)), establishing the general policy of the FSC and monitoring and overseeing policy implementation, including management of the FSC by MD. The MD is generally responsible for the operations of the FSC, creates and appoints FSC staff, subject to board approval, and coordinates and executes requests for assistance from foreign regulatory bodies.

36. The Board is appointed by the Executive Council for a period not exceeding three years. The FSCA provides that the council determine terms of commissioners, with a goal of having one-third of board members come up to the end of their terms every year.

Consideration is now being given to extending these terms. While the FSCA provides that the executive council can only remove a board member for cause, it does not require it to disclose grounds for removal. Consideration should be given to requiring such disclosure.

37. The FSCA gives the Council, on recommendation for the Board, the power to appoint the MD under terms and conditions of employment as it sees fit. Because of the MD's statutory powers over the supervision of the FSC, it may be preferable to prescribe a term of service, perhaps five years. In addition, the Board should be required to disclose publicly any reasons for dismissal of the MD.

38. The MD has long served as the highly qualified and respected head of the FSD, and his appointment as MD of the FSC was expected and fully appropriate. In practice, all Board members but one (who is statutorily required to be from outside the territory and whose name was put forward by the FCO) was selected from names put forward by the MD, although the Chief Minister did reject a number of the MD's suggestions. While the current Board appears familiar with the industry (it consists of primarily financial services industry personnel) and appears free from undue governmental and commercial pressures, it is possible that this could be due to in part to circumstances specific to the current government and MD. Consideration could be given to establishing a formal external advisory committee of experts publicly to consider and advise the executive council on board appointments and on appointment of the MD.

39. The Board has adopted rules and procedures for the board (including Procedures and Protocol Guidelines and a Code of Conduct), the organization of the FSC and the terms and conditions for staff, and the Guidelines for Operating Procedures for the Licensing and Supervisory Committee, which includes the Table of Authorized Levels of Decision-Making on Behalf of the FSC (Guidelines). These guidelines lay out, inter alia, those decisions that 
are to be taken by the Board and those that are to be taken by the FSC; and the details of the allocations of responsibilities between Board, Committee, and directors is clear, well thought out, and logical. ${ }^{10}$

40. The Board currently meets once a month, during which time it also reviews a memorandum prepared by the MD on the FSC's work for the previous month, including an overview of licenses granted, any advisories, and new initiatives. Decisions already taken by the Board include an order on approving jurisdictions for exchanges of information, codes of conduct for mutual funds, and a draft budget, which they are continuing to negotiate with the Executive Council though a subcommittee including the MD. However, there have been complaints from some in the private sector that there is a lack of transparency regarding the decision-making process of the board.

\section{Licensing and Supervisory Committee}

41. The FSC 's main functions are vested in a licensing and supervisory committee, which includes the MD, the Deputy MD, directors of the commission's regulatory and supervisory divisions, including banking and fiduciary services (which includes trust and company service providers/registered agents), insurance, investment business (mutual funds), and legal and enforcement. The committee reviews and acts on all applications for licenses for regulated persons, and supervises such persons to ensure that they continue to satisfy fit-and-proper criteria.

42. The guidelines adopted by the Board specify a process of peer review of committee decisions. They also require that all relevant documents, including recommendations for decisions, be first prepared by the relevant regulatory division and circulated a week prior to the meeting. This system appears to work well at ensuring quality and consistency of decisions. Under the guidelines, the committee need not provide written reasons for all of its decisions unless requested to do so. The guidelines could be amended to require written reasons for all denials, which could improve efficiency of the review process once appellate review of decisions becomes operational.

\section{Staffing and supervision}

43. The FSC performs its day-to-day functions through the various regulatory directorates. ${ }^{11}$ There are a few significant vacancies at the senior management level,

${ }^{10}$ Areas reserved for the Board include advising the Executive Council on any need governmental action (including with respect to the FSC budget); issuing directives, guidelines, codes of conduct, etc.; appointing advisory committees; preparation of the annual reports; approving jurisdictions for provision of assistance; granting or revoking exemptions from the FSCA, granting certain key changes in the terms of licensees; and any major enforcement actions, including the revoking of any licenses of a covered person. 
including the director of legal and enforcement (the Deputy MD, a qualified lawyer, has been filling this role), although this position is expected to be filled soon with a former Attorney General. There are also as-yet- unimplemented plans for appellate review of decisions, for a policy and research department, and an insolvency services department, and the director of at least one department is expected to retire soon. The FSC is seeking to fill these vacancies as soon as possible and is undertaking a broad search employing the use of international headhunting firms.

44. The FSC is staffed with approximately 75 professional employees, the vast majority of whom are involved with the relatively routine task of registration of IBCs in the Registry of Corporate Affairs. Of those assigned directly to the licensing and supervision of financial institutions, five are assigned to banking and fiduciary services; three to the insurance; and five to investment business.

45. These numbers are likely to be inadequate to maintain and improve the FSC's operations, once full on-site inspections begin in 2003. Furthermore, some of the staff that are below the levels of management and director lack in-depth knowledge of the regulated persons, nor do they have extensive regulatory and supervisory experience. However, it should be noted that, even though the FSC largely took over the duties and staff of the FSD, it has been in existence only since the beginning of 2002, and therefore is still in a period of gearing up for full operation. The FSC is aware of its staffing needs and is undertaking a strenuous effort to recruit and train new staff, including through the use of headhunters. In addition, the local community college has also begun a program in financial services. It would be helpful, however, if human resource needs were clearly specified in a detailed 3- to 5 -year recruitment and succession program to implement a long-term enhancement and deployment of skills-strategy.

46. There is often detailed and well-executed off-site inspection of relevant documents in the course of the granting of initial licenses, and in the course of license renewal (as well as on an ad hoc basis) including, where necessary, background checks. However, the most serious issue arises from the fact that the FSC has not yet fully implemented a comprehensive system to exercise all of its supervisory powers through a comprehensive audit and compliance system, including on-site inspections outside of the CSP sector. In addition, enforcement activities are undertaken on a basis that is in part ad hoc. The FSC is well aware of this deficiency, and has engaged KPMG to assist in designing such an audit program. Manuals have already been prepared, and the audit program and on-site inspections are expected to begin in 2003.

47. Another general weakness relates to the FSC's collection of information relating to the financial industry in general and of regulated persons in particular. Such information is ${ }^{11}$ Administrative functions are undertaken through the financial controller, operations
manager, and human resources manager. 
important to the efficient operations of all aspects of the FSC's work, including with respect to planning for improvements in supervision, adjustments to anticipated changes, and for the future needs of the industry; and the collection, analysis, and dissemination of such information should be improved. There has been an increasing and dedicated effort to engage in consultations with industry, including through considerable outreach efforts (particularly with respect to educating the industry and supervised persons as to new regulatory and supervisory requirements). However, the consultative process, whereby the FSC regularly consults with the industry, is in the process of becoming more regularized and deepened, especially with respect to feedback from the regulated persons. The FSC is consulting with industry on the design of a new prudential return, which is expected to be introduced at the end of 2003.

\section{STRENGTHS AND VULNERABILITIES IN THE FinANCIAL REgUlatory AND SUPERVISORY ARRANGEMENTS}

\section{Observance of Financial System Standards and Codes: Reports on Observance of Standards and Codes (ROSCs)}

\section{A. Summary Assessment of Compliance with the Basel Core Principles for Effective Banking Supervision}

\section{General}

48. This report provides an assessment of the BVI's compliance with the BCPs. The assessment was undertaken as part of the IMF Module 2 for Offshore Financial Centers. The conclusions of this report are based on an initial self-assessment of the authorities, supplemented by additional discussions between the team and the authorities. This assessment was prepared by Mr. Joseph O’Neill.

\section{Market structure}

49. There are 10 banks with total assets of US $\$ 2.71$ billion in the BVI. They operate under the BTCA and are subject to the supervision of the FSC. Six of these have a general license and can do business within and outside the BVI and the remaining four have restricted license and can only do business outside the BVI, with certain exceptions. All of these banks are primarily subsidiaries or branches of foreign banking groups. In addition, there is a GOB, the Development Bank of the Virgin Islands, which operates pursuant to the Development Bank of the Virgin Islands Ordinance (1974). The GOB engages in retail and commercial banking with total assets amounting to US\$56 million.

\section{General preconditions for effective banking supervision}

50. The BVI banking system is composed almost entirely of subsidiaries and branches of international banking institutions, each of which appear to be subject to adequate consolidated supervision (and the quality of which can be analyzed primarily by examining 
the supervision of the home jurisdiction). Accordingly, many of the deficiencies identified in this assessment are largely mitigated from a consolidated perspective. This assessment accepts that the FSC needs to balance the benefits that any additional regulatory burdens might bring to the safety and soundness of the system with the detriments caused by increased compliance costs. Detriments might include subsidiary or branch closings and fewer banking services for BVI residents.

51. The Financial Services Commission (FSC) implemented its current, limited on-site supervisory visits program during 2001 . The FSC is currently developing prudential regulations and more in-depth, on-site examination procedures that are expected to be implemented during 2003.

52. The BVI generally complies with the BCPs relating to Objectives, Powers, and Resources and Licensing. While the BVI lacks specific prudential regulations and requirements, it has required banks to report their compliance with relevant BIS papers. Furthermore, the supervisory efforts currently are limited to high-level questionnaires and discussions with management. Accordingly, the overall supervision of the banking system by the BVI is weak.

53. The GOB is currently not subject to prudential oversight. The authorities are in the process of proposing legislative amendments to have the GOB be fully subject to the FSC's supervision and regulation.

\section{Main findings}

\section{Objectives, Autonomy, Power and Resources (Core Principle 1)}

54. Prudential supervision and regulation for banking activities is the responsibility of the FSC. The Financial Services Commission Act of 2001 (FSC Act) clearly establishes the FSC's objectives, autonomy, powers, and resources and provides broad rule making powers. The FSC also has broad powers to take action against banks not complying with the legislation.

55. The head of the FSC currently has no fixed term for his appointment. Further, to enhance the FSC's autonomy, the BVI may consider establishing the position of the FSC's managing director subject to a fixed term.

56. The Development Bank of the Virgin Islands currently is not subject to prudential supervision, even though it is engaged in local retail banking.

\section{Licensing and Structure (Core Principles 2-5)}

57. The Bank and Trust Companies Act and the Bank and Trust Companies Regulations (1991), supplemented by the "Guidelines for Banking Licensing" (November 1993) establish adequate licensing requirements, consistent with the BCPs. The term "bank" is adequately limited to refer to entities engaged in the business of banking. 
58. Changes in control are subject to prior regulatory approval. Current laws and regulations do not include specific limitations as to acquisitions and investments.

\section{Prudential Regulation and Requirements (Core Principles 6-15)}

59. The BVI generally lacks detailed formal prudential regulation regarding capital, credit policies, reserves, large exposures, connected lending, market risk, liquidity, interest rate risk, and country risk. The FSC administratively requires the general license banks, and most restricted license banks, to comply with an 8 percent risk-based capital requirement.

60. Through the recently implemented on-site visits program, the FSC has begun to monitor how the various institutions manage their risk. Detailed questionnaires used during on-site visits cover the more relevant risks, including credit, foreign exchange, and liquidity risks. The prudential visits also include detailed questions relating to the corporate governance structure, including a specific section on the internal audit function. The current questionnaires do not cover certain issues, including country risk and connected lending.

61. The lack of clear regulatory requirements, coupled with the lack of detailed testing, results in a relatively weak prudential regulation framework. However, this deficiency is mitigated by the fact that the banking system is almost entirely composed of foreign banks subject to adequate consolidated supervision.

62. The FSC has adopted adequate AML policies that promote high ethical and professional standards in the financial sector to prevent the banking system from being used by criminal elements. No detailed on-site testing is yet being performed to ascertain that banks policies and procedures are in effect and are functioning properly.

\section{Methods of Ongoing Banking Supervision (Core Principles 16-20)}

63. In order to acquire a thorough understanding of banks' safety and soundness, bank supervision includes the combination of on-site and off-site procedures.

64. The FSC receives a balance sheet and income statement on a quarterly basis with additional memorandum information, and a maturity analysis of assets and liabilities. The regulatory reports are highly summarized and do not include sufficient detail (for example, levels of delinquency) to make detailed qualitative judgments or assessments of the institutions.

65. The FSC began its current limited on-site visits program in 2001. These visits consist of a meeting with top management to discuss the operations, performance, and management of the institutions. The FSC uses its "Bank Prudential Visit Questionnaire" as a basis to analyze the bank. The questionnaire includes inquiries as to the bank's management of credit risk, liquidity, foreign exchange risk, interest rate risk, and AML. The questionnaire also covers multiple general management issues, including the evaluation of management, evaluation of the internal audit function, and information technology. 
66. The level of detailed questioning, analysis and follow-up only provide a very broadlevel perspective of the institution. Due to the lack of detailed analysis and detailed testing, the supervisor does not have sufficient independent verification of the bank management representations or of the banks off-site regulatory reports.

\section{Information Requirements (Core Principle 21)}

67. The FSC requires the banks to file audited financial statements. The FSC accepts audited financial statements in accordance with the standards of a bank's country of origin.

68. The FSC does not require the branches to file audited financial statements. In addition, neither the FSC nor the banking industry publishes detailed information on the financial condition of the banks.

\section{Remedial Measures and Exit (Core Principle 22)}

69. The FSC has adequate legal powers to take corrective action when deemed necessary. However, due to the shortfall in the on-site and off-site supervision and weaknesses in the prudential standards, in practice, the remedial actions do not always occur on a timely basis. As the FSC strengthens its prudential standard regime and its on-site and off-site supervisory program, any weakness in the banking system should be detected on a timely basis for early corrective action.

\section{Cross-Border Banking (Core Principle 23-25)}

70. Currently, there are no banks incorporated in the BVI with foreign subsidiaries or foreign branches. The FSC has taken an active approach in establishing and maintaining communication with the home country supervisor of its banks.

71. The BTCA and regulations do not establish different standards for foreign banking entities. In practice, various prudential requirements for foreign branches are implemented by the consolidated supervisor, rather than the FSC.

\section{Staff commentary}

72. The BVI has been progressively implementing legal and administrative changes gradually to improve its supervision and oversight of the banking system.

73. The relatively recent enactment of the Financial Services Commission Act greatly improved the independence of the licensing, regulatory and supervisory procedures, and provided adequate resources for supervision. In 2001, the FSC implemented its on-site visits program. Through the on-site visits, the FSC obtains an understanding of the banks operations and monitor each bank's risk-management practices. 
74. The authorities represent that the GOB will be placed under the full regulatory and supervisory powers of the FSC. The team strongly encourages the authorities to implement this change as soon as possible, as the GOB has exhibited multiple weaknesses.

75. The FSC intends to issue guidance notes during the coming months that should address a wide variety of prudential requirement issues, including capital requirements, large exposures, connected lending, and related-party transactions. The FSC also expects to implement a more comprehensive on-site supervision module during the second half of 2003. Furthermore, the FSC is in the process of modifying its off-site reporting package to include detailed information on: (i) exposures to central governments; (ii) income and expense statements; (iii) securities subdivided by different categories (debt vs. equity and trading vs. investment/held to maturity); (iv) past-due loans and other assets; (v) repricing maturities; (vi) off-balance sheet items; (vii) derivatives; and (viii) risk-based capital calculation.

76. In relation to the guidance notes to be implemented in the future, the FSC may consider implementing broad prudential requirements, which require the board of directors and management of its banks to establish detailed policies and procedures addressing corporate governance, and risk management and prudential limits, subject to the approval of the FSC. Such types of regulations may provide the flexibility to the industry to operate under prudential standards akin to those in their home country, while maintaining the FSC's prerogative of obliging more stringent prudential policies and procedures to safeguard the local public interest.

77. The assessment team has not reviewed the proposed legislative changes, the proposed guidance notes, or the future on-site supervisory procedures. However, the changes as outlined by the authorities, including the combination of strengthening the regulatory framework and the off-site reporting requirements with the implementation of an in-depth, on-site examination program, should significantly enhance the supervisory effectiveness.

78. The FSC should consider establishing greater coordination with the consolidated supervisors to be adequately abreast of the dynamics of the consolidated banking organization and ascertain that the supervisory procedures and consolidated controls are applied appropriately in the BVI. Also, through close coordination, the FSC may be able to coordinate joint examinations of local operations and hence reduce the need for local supervisors.

79. In implementing on-site examination procedures, the FSC may wish to consider utilizing external auditors or other professionals to assist in performing certain regulatory detailed testing. 
Table 2. Recommended Action Plan to Improve Compliance of the Basel Core Principles

\begin{tabular}{|c|c|c|}
\hline Reference Principle & Recommended Action & Response of Authorities \\
\hline $\begin{array}{l}\text { Legal framework for bank } \\
\text { supervision(CP 1.3) }\end{array}$ & $\begin{array}{l}\text { Place the Development Bank } \\
\text { under the full authority of the } \\
\text { FSC. }\end{array}$ & $\begin{array}{l}\text { To be implemented by end- } 2003 \\
\text { or early } 2004 \text {. }\end{array}$ \\
\hline $\begin{array}{l}\text { Prudential Standards (CP } \\
5,6,7,8,9,10,11,12,13)\end{array}$ & \begin{tabular}{|l|} 
Implement prudential standards \\
consistent with international \\
standards and in manner to protect \\
the safety and soundness of the \\
system and the interests of \\
depositors and creditors. \\
\end{tabular} & See comments below. \\
\hline $\begin{array}{l}\text { Internal Control and Audit (CP } \\
\text { 13) }\end{array}$ & $\begin{array}{l}\text { Implement Corporate Governance } \\
\text { Standards and formal } \\
\text { requirements for internal audit. }\end{array}$ & See comments below. \\
\hline $\begin{array}{l}\text { On-site and off-site supervision } \\
\text { (CP 16,18) }\end{array}$ & $\begin{array}{l}\text { Implement on-site supervisory } \\
\text { program and implement changes } \\
\text { to off-site supervisory reporting } \\
\text { and analysis. }\end{array}$ & To be implemented. \\
\hline Information Validation (CP 19) & $\begin{array}{l}\text { As part of the implementation of } \\
\text { on-site supervision, include the } \\
\text { verification of regulatory reporting } \\
\text { with bank records. }\end{array}$ & To be implemented. \\
\hline Off-site supervision (CP 18) & \begin{tabular}{|l|} 
Design methodology and add \\
resources for effective and \\
comprehensive understanding and \\
analysis of audit and regulatory \\
reports. Should continuously \\
coordinate with home supervisor. \\
\end{tabular} & To be implemented. \\
\hline $\begin{array}{l}\text { Cooperation with Other } \\
\text { Supervisors (CP24) }\end{array}$ & $\begin{array}{l}\text { The FSC may consider increasing } \\
\text { interaction with home country } \\
\text { supervisors to increase } \\
\text { understanding of the consolidated } \\
\text { entity, risks assumed and } \\
\text { effectiveness of on-site/off-site } \\
\text { supervision. }\end{array}$ & To be implemented. \\
\hline
\end{tabular}

\section{Authorities' response}

80. The FSC has recently signed off on the Fiduciary/Company Management On-site Monitoring Program and the Banking On-site Monitoring Program is expected to be signed off on shortly. Although the FSC has not had a formal on-site inspection program, because of the size and nature of the banking business in the BVI, the Bank Prudential Visit Questionnaire has proven to be a good source of gaining adequate insights into the banks' operations. A new Bank Prudential Visit Questionnaire will allow the FSC to assess banks assets quality amongst other things. 
81. The FSC follows a risk based approach to supervision, which has led it to concentrate its supervisory work on, asset liability management, financial performance, capital adequacy requirements and management of credit risk.

82. With regards to concentration and liquidity risks, draft guidelines developed along international standards are currently with the banking industry for consultation. The proposed standards for credit policies and large exposure were developed to be consistent with the BCP. Although no specific rules have been set for banks' loan, investment policies and practices, since these are considered management responsibilities, the FSC expect banks to identify, monitor and control credit risk. Clear and precise rules with regards to large exposure have been developed. No specific loan classification or provisioning rules have been issued but the FSC expects banks to have internal policies that are consistent with international best practice.

83. Banks are required by the FSC to take reasonable care to establish and maintain systems and controls as appropriate to the nature and scale of their operations. BIS papers on Internal Controls and Operational Risks were issued to the banks as well as Interest Rate Risk. The nature of the banking systems in the BVI is such that there is an independent internal audit function conducted by either head office or parent bank. The quality of banks systems and controls and internal audits will be tested on an ongoing basis when the FSC commences on-site inspections.

84. Country risk is not significant for BVI banks as most loans are to domestic companies or individuals. Where there are country risks exposures, the exposures are to OECD and G10 countries. Connected lending is monitored from the prudential returns through the sections titles Related Party Deposits and Related Party Loans and Advances. All banks licenses have been approved and granted on the explicit understanding that the banks would be regulated according to the BIS standards.

85. The FSC now requires all branches to file audited financial statements commencing end of financial year 2003. A proposed amendment to the BTCA will require all banks to publish financial statements in the local press.

86. Prudential guidelines on the following are being drafted and are due to be implemented by end-2004: bank licensing; large exposures (completed); liquidity management (completed); credit concentration limits; risk weighted capital adequacy ratio; credit classification for provisioning purposes and income recognition; general principles for maintenance of accounting and other records and internal control systems; internet banking; corporate governance; related party transactions; relationship between financial institutions and external auditors; public disclosure of information; interest rate risk; country risk; market risk; code of practice for banks; and prudential returns (completed). 


\section{B. Summary Assessment of Implementation of the IOSCO Objectives and Principles of Securities Regulation}

\section{General}

87. This assessment covers the BVI securities sector. The main objectives of the assessment are to determine levels of observance of the IOSCO principles and to suggest areas where further development may be appropriate. The assessment was undertaken as part of the IMF Module 2 for Offshore Financial Centers. The conclusions of this report are based on an initial self-assessment of the authorities, supplemented by additional discussions between the team and the authorities. This assessment was prepared by Ms. Tanis MacLaren.

\section{Information and methodology used for assessment}

88. The assessment was based on interviews with staff of the FSC and individual industry members, a review of the laws, the rules, the guidance, and the procedures with respect to the securities regulatory regime, the draft Code of Practice, and the self-assessment provided by the FSC. The assessor used the IMF and World Bank Guidance Note for Assessing Implementation of IOSCO's Objectives and Principles of Securities Regulation.

89. The regulation of securities in the BVI was introduced with Mutual Funds Act, 1996, as amended (the MF Act) which was implemented in January 1998. The MF Act provides for the registration of public mutual funds and recognition of private and professional funds. It also governs the licensing of mutual fund managers and mutual fund administrators operating in or from the BVI.

90. The FSC was created as a single independent supervisory agency under the Financial Services Commission Act, 2001 (the FSCA). The functions and powers of the Authority under the FSCA establish the FSC as the financial supervisor for the territory. The act gives the FSC authority to administer, enforce, carry out and give effect to the provisions of the laws related to the financial services in the BVI. The FSC has the responsibility and authority to grant and revoke the licenses of banks, insurance companies, mutual fund managers and administrators, trust companies and company service providers, and to grant and revoke certificates of recognition and registration. It also is the authority responsible for the incorporation of companies under both the Companies Act and the International Business Companies Act, 1984. The FSCA authorizes the Commission to conduct examinations of financial institutions, regulated persons and corporations, to impose levies, and to impose and collect fees. The legal system in the BVI operates under common law principles.

91. The FSCA and the MF Act provide the main legal framework for the supervision of securities activities in the BVI. This legislation is supplemented by the Financial Services (International Cooperation) Act, 2000 (FS(IC)A), which sets out detailed requirements for information sharing with foreign regulators and law enforcement agencies.

92. The BVI is a major jurisdiction for the incorporation of mutual funds. At the end of September 2002, a total of 2,606 mutual funds had been registered or recognized in the BVI, 
up from 2,346 at the end of 2001, an increase of more than 11 percent in nine months. About 8 percent of these are public mutual funds that may be sold by prospectus to any investor. The rest are either professional funds (sold to sophisticated purchasers only) or private funds, where offers to the public are prohibited and the number of investors must be fewer than 50 .

93. The FSC, under the MF Act, also licenses mutual fund administrators and managers operating in or from the jurisdiction. As at the end of September 2002, 490 licenses had been granted, although this number does not reflect the total number of active licenses. One fund administration and 75 fund management licenses were granted during the first nine months of 2002. Mutual funds are not required to have managers or administrators that are licensed by the FSC. Very few of the licensed managers or administrators are physically located in the territory. The legislation in the BVI presently gives the FSC no authority to regulate other market participants, such as portfolio managers, broker-dealers or underwriters and there is no data on the extent of this business that might be carried on in the BVI at this time.

94. There is no stock exchange in the BVI, nor is there any facility for the issue of securities other than mutual funds. There is no retail market for securities of any kind in the jurisdiction. The BVI Association of Mutual Fund Practitioners, a trade association, was formed in late 2001. There are no self-regulatory organizations in the territory.

\section{General preconditions for effective securities regulation}

95. The general preconditions for effective securities regulation in the BVI appear to be present. There are no significant barriers to entry and exit for market participants.

Competition is encouraged and foreign participation is welcomed. The legal system supports the operations of the FSC and effective regulation of mutual funds and their administrators and managers. The bankruptcy legislation in the jurisdiction is outdated. However, a much more modern Insolvency Act has been drafted and it is to be introduced to the legislature shortly. The regulator has legally enforceable powers of decision and action. The legal and accounting resources available to market participants do not pose constraints. The taxation framework is supportive to the operations of the industry in or from the jurisdiction.

\section{Main findings-summary}

96. The Regulator (Principles 1-5). The responsibilities of FSC are clear and objective. It is operationally independent and publicly accountable to the government and to the administrative courts in the exercise of its functions. The staff of the FSC meet high expectations of professionalism in their work. The processes followed are clear and consistently applied. All of the laws that FSC administers are publicly available, at least within the BVI. The FSC might also want to consider additional transparency regarding the processes followed, particularly regarding its consultation process. The consultation process might benefit from being made more open and inclusive in order to get input from the public, not just local market participants. However, it should be noted that local counsel normally responds on behalf of the offshore community, and that the Mutual Funds Advisory Committee is active in representing both on and offshore investors. 
97. The FSC does not have authority over the full range of securities activities and regulation covered by the IOSCO Principles. There are gaps, but these are in areas where there are no evident activities in the BVI at the present time. Should this situation change, the authority given to the FSC under the FSCA and other financial services legislation would have to be expanded accordingly.

98. Self-Regulation (Principles 6-7). There are no self-regulatory organizations in the BVI. Given the current industry structure and activities, this is not inappropriate.

99. Enforcement (Principles 8-10). The FSC has a comprehensive array of inspection, investigation, surveillance and enforcement powers. There are some limitations placed on when these powers may be exercised (such as needing a suspicion of a breach of the law before an examiner may be appointed) that could be eliminated, although the Division is of the belief that suspicion is a sufficiently low bar. The monetary penalties that may be imposed for a breach of the law may not be an effective deterrent and should be reexamined. The most serious issue arises from the fact that the FSC has not implemented an effective system to exercise its powers in these areas. There is not yet a comprehensive system of onsite or off-site inspections and enforcement activities are undertaken on an ad hoc basis. A new computer based audit and inspection program is being developed for implementation in 2003, as are regular reporting requirements for fund managers and administrators, which will improve activities in this area. The most pressing problem is the need for significant additional resources to implement an effective system of oversight of fund managers and administrators and of the mutual funds themselves. Also, the FSC's investigation and enforcement abilities are limited by the lack of staff.

100. Cooperation in Regulation (Principles 11-13). The FSC has very broad authority to share information with its domestic and foreign counterparts. There are no significant practical impediments to providing assistance to foreign regulators that need to make inquiries in the course of carrying out their regulatory activities. The relevant provisions in the legislation dealing with information sharing and providing assistance should be conformed so that there are no artificial constraints on what can be shared and with whom. For example, the definitions used in the FSCA should be revised to ensure they do not limit the ability of the FSC to share information with other regulators, where those regulators are making inquiries in the exercise of their jurisdiction over securities activities over which the FSC has no corresponding authority, such as market manipulation.

101. Issuer Regulation (Principles 14-16). There are no primary market issues of securities in the BVI, other than mutual funds and no market for corporate control. Therefore, the fact that the FSC has no statutory authority in this area is not a weakness. Nevertheless, it is worth noting that the accounting and auditing standards applied are high and of an internationally acceptable quality, although the processes for approving an auditor and recognizing a jurisdiction for the purposes of the MF Act would be better if they included an assessment of the quality of the accounting and auditing standards to be applied. 
102. Mutual Fund Regulation (Principles 17-20). Entry standards for fund managers and administrators are generally satisfactory. The rules governing conflicts of interest between fund managers, their related companies and the funds that they manage need to be addressed more comprehensively. Requirements regarding business conduct rules and requirements for books and records, internal controls and risk management systems for mutual fund managers and administrators should be strengthened. In particular, there should be an express requirement applicable to all market participants that mutual fund assets must be segregated from the assets of the fund manager, custodian or other service providers. The initial disclosure (prospectus) requirements for public mutual funds should be set out in a regulation and the continuous disclosure obligations of mutual funds need to be improved; in particular, the public disclosure of material changes should be more timely. These matters are to be addressed in the draft Code of Practice. The FSC should establish a supervision program for fund managers and administrators, which would combine periodic receipt and review of financial information and other reports and on-site visits.

103. Market Intermediary Regulation (Principles 21-24). At the present time, market intermediaries are not subject to regulation in the BVI. As there does not appear to be any retail securities intermediation activities being carried on, this gap does not appear to be serious. We did note that the Commission has recommended that the government introduce legislation to govern the activities of all persons carrying on investment business in the BVI, and the draft Investment Business Act should adequately address these issues.

104. Secondary Markets Regulation (Principles 25-30). The FSC has no authority to oversee the activities of securities exchanges, other trading systems or clearing and settlement systems. However, as there is no organized market in securities in the BVI nor any trading or clearing and settlement system operating in or from the BVI, this poses no particular issue. The FSC does not expect that any of these facilities will be established in the $\mathrm{BVI}$ in the foreseeable future. 


\section{Recommended action plan and authorities' response}

Table 3. Recommended Actions to Improve Implementation of the IOSCO Objectives and Principles of Securities Regulation

\begin{tabular}{|c|c|c|}
\hline Reference Principle & Recommended Action & Response of Authorities \\
\hline Principle 2 & $\begin{array}{l}\text { Consider amending the } \\
\text { legislation to require the FSC to } \\
\text { give reasons for all non-routine } \\
\text { decisions even when not } \\
\text { requested. } \\
\text { Consider developing a more } \\
\text { detailed conflicts policy for } \\
\text { board members. }\end{array}$ & Under consideration. \\
\hline Principle 3 & $\begin{array}{l}\text { Increase staff resources for } \\
\text { ongoing supervision and } \\
\text { enforcement. }\end{array}$ & To be implemented. \\
\hline Principle 4 & $\begin{array}{l}\text { Make the detailed licensing and } \\
\text { approval processes and } \\
\text { requirements publicly available. } \\
\text { Enhance the breadth and the } \\
\text { transparency of the consultation } \\
\text { process. }\end{array}$ & $\begin{array}{l}\text { Forms, specific requirements and } \\
\text { checklists are made available } \\
\text { (though not on the website) to } \\
\text { the public. In addition, training is } \\
\text { open to all members of the local } \\
\text { regulated population. It is the } \\
\text { intention to include more } \\
\text { information on the website. } \\
\text { Consultation process is being } \\
\text { enhanced and a more rigorous } \\
\text { consultation with the Mutual } \\
\text { Funds Advisory Committee is } \\
\text { already taking place. } \\
\text { Consideration is being given to } \\
\text { including application forms and } \\
\text { the public register on the FSC } \\
\text { website. }\end{array}$ \\
\hline Principle 9 & $\begin{array}{l}\text { The fines that may be imposed } \\
\text { under the FSCA and Ensure that } \\
\text { sanctions are set at a level to be } \\
\text { an effective deterrent. }\end{array}$ & Under consideration. \\
\hline Principle 10 & $\begin{array}{l}\text { Take all necessary actions to } \\
\text { increase staff resources for } \\
\text { inspections and enforcement. } \\
\text { The completion and } \\
\text { implementation of the new audit } \\
\text { and compliance program should } \\
\text { also be expedited. }\end{array}$ & $\begin{array}{l}\text { Appropriate actions to be } \\
\text { undertaken. } \\
\text { The audit and compliance } \\
\text { program is finalized but cannot } \\
\text { be implemented until the Code of } \\
\text { Practice is issued (against which } \\
\text { firms will be measured). } \\
\text { Expected to be implemented end } \\
\text { of Q1 } 2004 \text {. }\end{array}$ \\
\hline
\end{tabular}




\begin{tabular}{|c|c|c|}
\hline Reference Principle & Recommended Action & Response of Authorities \\
\hline Principle 11 & $\begin{array}{l}\text { The legislative language relating } \\
\text { to information sharing should be } \\
\text { broadened to eliminate any need } \\
\text { for the foreign regulator to be } \\
\text { exercising powers and duties } \\
\text { corresponding to those granted } \\
\text { the FSC under the listed BVI } \\
\text { financial services legislation. }\end{array}$ & Under consideration. \\
\hline Principle 16 & $\begin{array}{l}\text { FSC should make an assessment } \\
\text { of the quality of the accounting } \\
\text { principles and auditing standards } \\
\text { applicable in a jurisdiction before } \\
\text { approving an auditor or } \\
\text { recognizing a jurisdiction under } \\
\text { the MF Act. The standards and } \\
\text { principles should be equivalent } \\
\text { to those of the IAS. }\end{array}$ & Agree, expected end of Q1 2004. \\
\hline Principle 17 & $\begin{array}{l}\text { Mutual fund conflicts of interest } \\
\text { should be dealt with more } \\
\text { comprehensively. All of the } \\
\text { relationships between the } \\
\text { managers, administrators, other } \\
\text { functionaries and service } \\
\text { providers should be required to } \\
\text { be disclosed. } \\
\text { Mutual funds, managers and } \\
\text { administrators should be required } \\
\text { to file annual audited financial } \\
\text { statements with the FSC. } \\
\text { Managers and administrators } \\
\text { should also be required to file } \\
\text { other regulatory reports. } \\
\text { Institute a program of regular } \\
\text { inspections of all of these } \\
\text { entities. }\end{array}$ & $\begin{array}{l}\text { This will be a formal } \\
\text { requirement under the prospectus } \\
\text { requirements in proposed public } \\
\text { fund regulations. However, } \\
\text { currently informally a } \\
\text { requirement through the } \\
\text { application vetting process. } \\
\text { Other conflicts are also dealt } \\
\text { with in the draft Code of } \\
\text { Practice. Reporting (financial } \\
\text { and other) requirements are } \\
\text { included in the draft Code of } \\
\text { Practice. Public mutual funds are } \\
\text { required to prepare annual } \\
\text { accounts though not to file them; } \\
\text { these will be a requirement in the } \\
\text { proposed public fund regulations } \\
\text { Expected end of Q1 } 2004 \text { (Code } \\
\text { of Practice) and end of Q2 } 2004 \\
\text { (Proposed Public Funds } \\
\text { Regulations). }\end{array}$ \\
\hline Principle 18 & $\begin{array}{l}\text { Impose specific requirements } \\
\text { regarding books and records and } \\
\text { asset segregation requirements } \\
\text { that apply to all functionaries } \\
\text { (managers, administrators, } \\
\text { custodians and any other service } \\
\text { providers) who hold BVI } \\
\text { registered public mutual fund } \\
\text { assets. }\end{array}$ & $\begin{array}{l}\text { Agree, these are predominantly } \\
\text { covered for managers and } \\
\text { administrators in the draft Code } \\
\text { of Practice. FSC has no remit } \\
\text { over custodians or other } \\
\text { functionaries. Expected end of } \\
\text { Q1 } 2004 \text {. }\end{array}$ \\
\hline
\end{tabular}




\begin{tabular}{|c|c|c|}
\hline Reference Principle & Recommended Action & Response of Authorities \\
\hline Principle 19 & $\begin{array}{l}\text { Issue prospectus regulations for } \\
\text { public mutual funds. } \\
\text { Require public mutual funds to } \\
\text { make immediate disclosure of } \\
\text { any material changes and to } \\
\text { make these changes known to } \\
\text { investors in a timely fashion. } \\
\text { Statutory liability for } \\
\text { misrepresentations in a mutual } \\
\text { fund prospectus should be } \\
\text { extended to all parties involved } \\
\text { in preparing or authorizing the } \\
\text { prospectus. }\end{array}$ & $\begin{array}{l}\text { Agree, to be included in } \\
\text { proposed public fund regulations, } \\
\text { expected end of Q2 } 2004 \text {. } \\
\text { Agree, though already a } \\
\text { requirement to notify FSC of any } \\
\text { material changes to that } \\
\text { information supplied at time of } \\
\text { application, expected end of Q2 } \\
2004 \text {. } \\
\text { Disagree, will be difficult to } \\
\text { determine who is responsible; } \\
\text { ultimately the directors of the } \\
\text { fund are responsible. }\end{array}$ \\
\hline Principle 20 & $\begin{array}{l}\text { Enact binding rules on mutual } \\
\text { fund asset valuations and related } \\
\text { disclosure provisions. } \\
\text { Prohibit public mutual funds } \\
\text { from ceasing to redeem its } \\
\text { securities without notification to } \\
\text { the FSC. }\end{array}$ & $\begin{array}{l}\text { Agree, for public mutual funds } \\
\text { only; these will be included in } \\
\text { proposed public fund regulations, } \\
\text { expected end of Q2 } 2004 \text {. } \\
\text { Partially agree, would be prudent } \\
\text { to require notification of any } \\
\text { cessation as could be an } \\
\text { indication of problems with the } \\
\text { fund, expected end of Q2 } 2004 \text {. }\end{array}$ \\
\hline
\end{tabular}

\section{Summary Assessment of Compliance with the International Association of Insurance Supervisors (IAIS) Insurance Core Principles}

\section{General}

105. The assessment of the FSC's compliance with the IAIS Insurance Core Principles was based on: (1) a self-assessment against IAIS Core Principles; (2) relevant laws and regulations; (3) analysis of FSC practices and procedures, and (4) discussions with supervisory staff of the FSC. This ROSC was prepared as a part of the Offshore Financial Center assessment of the territory. This assessment was prepared by Mr. Tomas Power.

106. The IAIS Core Principles Methodology was the standard used by the mission. The legal framework for the British Virgin Islands insurance sector is based on the Financial Services (International Cooperation) Act, 2000, (FSC Act). There is also a sector-specific law and regulations (The Insurance Act of 1994 and the Insurance Regulations of 1995). Supervision of the sector is performed by the office of the director: Insurance Business within the FSC. The supervisory staff of the FSC, especially the insurance director and his staff, cooperated extensively in the assessment by preparing a self-assessment against IAIS Core Principles and by making themselves available to meet with mission members at every opportunity. 


\section{Institutional and market structure-overview}

107. The latest available data indicate that there are 293 insurance companies licensed in the BVI. There are a total of 263 captive insurers and 241 of the captives are organized to insure U.S.-based risks. ${ }^{12}$

108. The domestic insurance activity generated approximately US $\$ 40$ million in premium, while the captive industry wrote over US $\$ 400$ million. Approximately 95 percent of the captive business is written by single-parent captives.

109. There are 13 insurance agents, 11 insurance brokers, 12 insurance managers, and 7 loss adjusters.

110. The need or opportunity for business corporations to utilize risk-financing or risk management mechanisms alternative to the traditional commercial insurance markets has created the demand for jurisdictions that will authorize formation of captive insurers under "user friendly" standards. The organizer of the captive gains the advantages to his business or his tax status that may arise from his own jurisdiction's laws and the BVI gains licensing revenue and creates jobs. The availability of a captive insurer facility also adds as to the attractiveness of the BVI for other Offshore Financial Center operations. There has been a steady growth of captives world-wide in the recent past of approximately 10 percent annually. The growth rate of the BVI captives closely tracks this global growth. It was noted in discussions with the private sector (as well as by the FSC professionals) that the fixed costs applicable to a BVI-based captive offer significant savings compared to other jurisdictions seeking captives. Also, some of the major market players offering management services to captives are beginning to establish a presence in the territory. This signals a likely increase in the number of captives and not a battle for market share.

\section{General preconditions for effective insurance supervision}

111. Since the beginning of formalized insurance regulation (undertaken in the nineteenth century by Elizur Wright in Massachusetts in the United States) the major concern of insurance regulation has been protection of policyholders. While such concerns are certainly important in the twenty-first century, the nature of the insurance mechanism and the

\footnotetext{
${ }^{12}$ A captive insurer is one that is organized and operated primarily to insure the other business risks of the founders of the firm. Insurance is not sold to the public at large. Often, groups of similar businesses, presumably with similar risk exposures, will organize such insurers. Captive insurers generally have comparatively low capitalization requirements compared to standard commercial insurance companies. In some jurisdictions, capital does not have to be paid in but can consist of letters of credit or other types of instruments.
} 
business of insurance have undergone fundamental changes in both scope of services and breadth of markets.

112. The International Association of Insurance Supervisors has recognized the preconditions for effective insurance supervision through the promulgation of the Core Principles. We have undertaken a comprehensive discussion and assessment of each of the Core Principles and we have noted the conformance of the BVI to them.

113. Generally, effective insurance supervision requires the existence of an agency charged clearly with the regulation of the business of insurance, such agency having sufficient independence and professional staff and resources in order to undertake its obligations. The mission of the insurance supervisory agency is the monitoring of the financial condition of insurers in order quickly to detect situations that may, presently or prospectively, prove hazardous or injurious to policyholders or the public; monitor compliance with applicable laws; and maintain an orderly, transparent and competitive marketplace. This organization also requires a statutory mandate clearly delegating to it such powers as are necessary to execute its mission ably and rapidly. The agency must have appropriate standards for licensing of those involved in the broad insurance industry and ongoing monitoring of the fitness and capacity of market players. There must be prudential standards governing the actual operations and financial condition of insurance firms and opportunity for the supervisory authority to assess the performance of the various firms and take swift remedial actions where appropriate. The business of insurance being in many ways an international enterprise, there must be concerted efforts of the supervisor to cooperate with and share information with other organizations.

\section{Effective supervision of captive insurers}

114. Prudential rules for captive insurers often differ in material respects from those applicable to insurers marketing for the general public. However, these differences ordinarily pertain only to recognizing the fundamental differences between the two types of organizations and not to the necessity for monitoring solvency and assuring that proper care is taken in monitoring investments, asset and liability matching, and sufficiency of reserves.

115. At first glance, the need for regulatory oversight of captives may seem unnecessary in view of the fact that the "policyholder" is also the owner of the firm and the person whose interests are at stake. However, in many cases, the type of coverage applicable is liability insurance. In liability insurance, even though the tortfeasor, for example, is the insured and the obligation of the insurance company is to indemnify the insured for his losses (for example, having to pay a liability judgment) there is always a third-party beneficiary - the person damaged by the act of the insured.

116. While insurance attorneys may argue about the duty that an insurer owes to a thirdparty beneficiary, the duty of the insurance regulator clearly is to adopt standards that will maintain confidence that insurance companies can be expected to have the ability to meet their contractual obligations, irrespective of the ownership of the insurer. Also, being covered 
by particular types of liability insurance is often a prerequisite to practicing a profession or trade. If the liability insurance being offered to meet that requirement is within the control of the insured through the mechanism of a captive insurer, sound public policy dictates that insurance regulators have an affirmative duty to exercise the same degree of care in supervising those types of entities that they have in supervising commercial insurance firms.

\section{Main findings}

117. The BVI has enacted a modern and comprehensive statute-The Financial Services (International Cooperation) Act, 2000, (FSC Act). The sector-specific law and regulations (The Insurance Act of 1994 and the Insurance Regulations of 1995), however, have not been amended to add additional standards. While the BVI is dominated by so-called captive insurers, there is still substantial insurance business for the risks resident, located or to be performed in the BVI. The current state of the insurance law and regulations does not provide precise protections for these policyholders in establishing a formal dispute resolution mechanism. However, there is an informal system of investigating complaints and when the inspection process begins, this weakness will be addressed.

118. The BVI does not meet all of the IAIS Core Principles, having deficiencies in Internal Controls, Corporate Governance, and On-Site Inspections. Also, the staff of the FSC charged with the responsibility of supervising the business of insurance is quite small. The director, however, is a seasoned insurance professional who has demonstrated strong capacitybuilding and institution-building results with admittedly limited resources. Except for the two most senior persons, the staff has limited training in insurance regulation and supervision. Recruiting and retention of qualified staff has been a problem. However, senior management of the FSC is aware of all of these deficiencies and is the process of addressing all of these issues. Moreover, the senior staff are currently training the more junior members, particularly in the area of on-site inspections. This effort, when completed, will likely address most of the material weaknesses noted because the knowledge of the industry that on-site inspections will take place, in itself, acts as an effective enforcement tool and will prompt compliance in the areas of corporate governance and internal control procedures.

119. The main findings of the mission may be described as follows:

- $\quad$ The sector-specific law and regulations (The Insurance Act of 1994 and the Insurance Regulations of 1995) have not been amended to add additional standards. However, a re-draft of the law and regulations is in progress and will result in a full harmonization of those with the broad powers under the Financial Services Act.

- While the BVI is dominated by so-called captive insurers, there is still substantial insurance business for the risks resident, located, or to be performed within the BVI. The current state of the insurance law and regulations does not provide precise protections for these policyholders in establishing a formal dispute resolution mechanism. However, there is an informal system of investigating complaints and when the inspection process begins, this weakness will be addressed. 
- $\quad$ The BVI does not meet all of the IAIS Core Principles-Internal Controls, Corporate Governance, and On-Site Inspections.

- $\quad$ The FSC should require comprehensive errors and omissions (E\&O), fidelity and surety, and professional liability insurance for all intermediaries.

\section{Recommended action plan and authorities' response}

\section{Table 4. Recommended Action Plan}

\begin{tabular}{|c|c|c|}
\hline Findings & Follow-Up Action Plan & Response of the Authorities \\
\hline $\begin{array}{l}\text { Need for implementation of the } \\
\text { on-site inspection process and } \\
\text { continue training of staff. }\end{array}$ & $\begin{array}{l}\text { Manuals have been completed; } \\
\text { train staff on use; field-test; } \\
\text { possible technical assistance in } \\
\text { conducting initial inspections } \\
\text { and in other capacity-building } \\
\text { programs. }\end{array}$ & $\begin{array}{l}\text { Ad hoc on-site inspections of } \\
\text { insurance managers have taken } \\
\text { place in the second half of } 2003 \text {, } \\
\text { focusing on specific individual and } \\
\text { groups of companies. } \\
\text { An on-site inspection program for } \\
\text { Insurance Managers has been } \\
\text { designed. Training is being } \\
\text { provided to Insurance Division } \\
\text { staff. The program will be } \\
\text { introduced in the first quarter } 2004 \text {. }\end{array}$ \\
\hline $\begin{array}{l}\text { Need for rules governing the } \\
\text { operations of managers and } \\
\text { other intermediaries that will } \\
\text { strengthen the corporate } \\
\text { governance and internal control } \\
\text { procedures standards applicable } \\
\text { in the BVI. }\end{array}$ & $\begin{array}{l}\text { Assess the suitability of various } \\
\text { IAIS Guidance notes; discuss } \\
\text { with intermediaries and other } \\
\text { stakeholders; and then } \\
\text { promulgate appropriate } \\
\text { standards. }\end{array}$ & $\begin{array}{l}\text { Draft guidance notes consistent } \\
\text { with IAIS standards to be issued. }\end{array}$ \\
\hline $\begin{array}{l}\text { Require compulsory Errors and } \\
\text { Omissions, Fidelity and Surety } \\
\text { and Professional Liability } \\
\text { insurance for insurance } \\
\text { managers, compliance officers } \\
\text { and insurance agents and brokers } \\
\text { based on a sliding scale of level } \\
\text { of exposure to various hazards. }\end{array}$ & $\begin{array}{l}\text { Determine appropriate types of } \\
\text { insurance necessary; discuss } \\
\text { with industry; assess appropriate } \\
\text { levels of exposure; promulgate } \\
\text { requirements. }\end{array}$ & $\begin{array}{l}\text { A current proposed amendment to } \\
\text { the Insurance Act, } 1994 \text { includes } \\
\text { the requirement that the Insurance } \\
\text { Manager, Agent, Broker or } \\
\text { Insurance Intermediary have in } \\
\text { force Professional Indemnity } \\
\text { insurance, for such amount as may } \\
\text { be prescribed in the Regulations. }\end{array}$ \\
\hline $\begin{array}{l}\text { Revise the Insurance Act and } \\
\text { Regulations in order to } \\
\text { harmonize them with the } \\
\text { increased authority of the FSC. }\end{array}$ & $\begin{array}{l}\text { Prepare appropriate draft } \\
\text { language and explanations; } \\
\text { submit to legal council; table } \\
\text { law. }\end{array}$ & $\begin{array}{l}\text { Draft amendments to the Insurance } \\
\text { Act, } 1994 \text { and Insurance } \\
\text { Regulations, } 1995 \text { have been } \\
\text { prepared. They are currently being } \\
\text { further amended to ensure } \\
\text { harmonization with the Insolvency } \\
\text { Amendment Act, 2003. It is } \\
\text { expected that the amendments will } \\
\text { take effect in the first half of } 2004 \text {. }\end{array}$ \\
\hline
\end{tabular}




\section{Summary Assessments of Compliance with the FATF Recommendations for Anti-Money Laundering and Combating the Financing of Terrorism}

\section{Introduction}

120. This Report on the Observance of Standards and Codes for the FATF 40

Recommendations for AML and 8 Special Recommendations Combating the Financing of Terrorism was prepared by a team composed of Pramita Moni Sengupta, Legal Department, IMF, Marie-Christine Dupuis, United Nations Global Program Against Money Laundering, and Atle Roaldsøy, Ministry of Justice, Norway, an independent AML/CFT assessor (IAE), who was responsible for the assessment of the effectiveness of criminal justice measures and effectiveness of implementation of preventive measures in financial sectors that are vulnerable to money laundering but are not macro-relevant.

121. The report provides a summary of the level of observance with the FATF $40+8$ Recommendations and provides recommendations to strengthen observance. The views expressed in this document are those of the assessment team and do not necessarily reflect the views of the Government of the BVI or the Executive Board of the IMF.

\section{Information and methodology used for the assessment}

122. The assessors reviewed the relevant AML/CFT laws and regulations, and supervisory and regulatory systems, in place to deter money laundering and financing of terrorism among banking, insurance and securities, as well as for trust and company service providers, which in the BVI are macro-relevant and vulnerable to money laundering. The IAE reviewed the effectiveness of implementation for lawyers, accountants, and money remitters that are vulnerable to money laundering but not macro-relevant, as well as the capacity and implementation of criminal law enforcement systems. ${ }^{13}$ The assessment is based on the information available at the time it was completed in November 2002.

\section{Main findings}

123. As a major financial center and dominant place of registration for international business companies, and as a possible transshipment corridor for the trafficking of cocaine from producer countries to the south and consumer countries to the north, the BVI is vulnerable to ML and FT.

124. An adequate legal framework has been established to criminalize ML and FT, to facilitate international cooperation in ML and FT matters, and to provide for confiscation and forfeiture of assets associated with ML and FT. The Proceeds of Criminal Conduct Act (PCCA) is the primary instrument for criminal provisions and confiscation. International

${ }^{13}$ Aspects of the assessment for which the IAE is responsible are marked in italics. 
cooperation in criminal matters is encompassed by the Criminal Justice (International Cooperation) Act (CJIC) and the Financial Services (International Cooperation) Act (FSIC). Financing of Terrorism is addressed by Two Statutory Instruments No. 3366 in 2001, The Terrorism (United Nations Measures) (Overseas Territories) Order, and No. 1822 in 2002, the Anti-Terrorism (Financial and Other Measure) Overseas Territories), which address the major requirements for FT under the 1999 United Nations Convention for the Suppression of Financing of Terrorism.

\section{The BVI ML criminal provisions are generally consistent with the Vienna and} Palermo Conventions, and FT is criminalized consistent with the International Convention for the Suppression of the Financing of Terrorism. The criminal provisions for ML are not extensively used for prosecution because most ML evidence is provided for foreign prosecutions where, frequently, the cases are stronger and there are more resources to conduct complex investigations and prosecutions.

126. Confiscation of proceeds from criminal conduct, including direct and indirect benefit derived from money laundering, and provisional measures for freezing of assets are adequate. However, the forfeiture provisions applying to property laundered and instrumentalities of ML are not clearly defined in the law outside of the context of narcotics, and a relatively short list of relevant crimes. There are specific provisions for the freezing, restraint and forfeiture of assets used to finance terrorism or intended to be used to support terrorist activities, but the law does not provide specifically for forfeiture of all property laundered and instrumentalities associated with an ML offense.

\section{The PCCA established the Reporting Authority (RA) as the FIU responsible for the} receipt and processing of disclosures of suspicious financial transactions that are received in the form of Suspicious Transaction Reports (STRs). The RA is a statutory body with limited primary powers to receive STRs and to disseminate these to law enforcement both locally and abroad. The RA mainly derives its financial intelligence and investigative powers from its members, who are the managing director of the Financial Services Commission, the head of the Police Financial Investigations Unit of the Royal Virgin Islands Police Force (Police FINU) ${ }^{14}$ and a Senior Crown Council from the AGC. It appears that the main financial intelligence analysis and subsequent investigations required are conducted on an integrated basis by the Police FINU. The structure, while clearly working at present, is not formalized and the scope of the RA's mandate is therefore somewhat unclear, particularly how the tasks and powers are divided between the RA and the Police FINU. The lack of a clear distinction between the responsibilities and mandates of the $R A$ and Police FINU may pose some problems, as more STRs are generated. Although the blurring of functions might have its practical advantages, it could be argued that the present arrangement might interfere with principles of independence and professional secrecy.

14 The acronym FINU is used to avoid confusion with Financial Intelligence Units or FIUs. 
128. Suspicious transaction reporting is a voluntary/defensive requirement under the PCCA, i.e., a regulated person can file an STR as a defense against a charge of ML, which may be the reason for the relatively low numbers of STRs filed for the size of the financial sector. The RA has no systematic contact with the reporting institutions, but they do attend a number of meetings and issue alerts from time to time on scams or attempted fraud schemes. While the current system has been sufficient for generating STRs for obviously suspicious transactions and activities, there may be some gaps in filing of reports for which the situation is questionable, but the reporting party has refused the transaction rather than file an STR. On a systemic level, opportunities for detecting suspicious or unusual activities in this vein may be lost. The law does not provide for the RA or other competent authority to order blocking or freezing of transactions administratively when an STR is filed.

129. The absence of detailed statistics that are adequately broken down makes it difficult for the authorities to derive information of either a more general nature or with more strategic value. Thereby, the authorities lose a possibility for feedback to the reporting institutions, and they are also hampered with regard to identifying areas of concern and potential improvement in connection with the reporting system. The BVI authorities have been satisfied with the implementation and effectiveness of the voluntary reporting of suspicious transactions. The number of reports - and information given on their use - might indicate that there is a need for a mandatory reporting system, wherein the law and regulations would mandate STRs' filing when certain objective criteria are met. Mandatory reporting, established by statute, is generally regarded as an important measure for protecting the financial industry from being misused for money-laundering purposes.

130. As a general matter, the Police FINU has responsibility for investigating all financial crimes, including money-laundering offences. Reports on the financing of terrorism are to be reported to the governor, who provides the information to the AGC for action. The AGC are vested with prosecutorial responsibility and for providing mutual legal assistance from formal international requests and mutual legal assistance treaties (MLAT)s.

\section{Because of the BVI's dominant role in the formation of international business} companies, the Police FINU spends considerable time in executing mutual legal assistance. As a consequence, domestically initiated investigations are few. Doubtlessly, the AGC and the Police FINU are well capable of conducting money-laundering investigations, but resources are scarce and the number of domestic cases very limited. The number of staff clearly puts limitations to the possibility of undertaking in-depth investigations both in relation to domestic and international cases. The investigative powers available seem generally adequate. The authorities are currently reviewing the legal framework to possibly enhance the scope and effectiveness of investigative tools. Targeted statistics related to law-enforcement activities, including freezing, seizing, and confiscating of the proceeds of crime, should be developed.

132. Some statistics on law-enforcement activities in this area is available, but they are not comprehensive. Some statistics on seizures are developed by the FINU for internal purposes. According to information provided by the authorities, BVI has assisted foreign authorities in 
the freezing of substantial values over the last decade. The substantial number of requests for assistance strongly indicates that the present staffing of the FINU is not sufficient to take on a more active approach with regard to ML/FT cases. The nature of these crimes is inherently concealed, and sufficient, and qualified manpower, as well appropriate technical means, are crucial in order to successfully reveal, investigate, and prosecute the cases.

133. The authorities have taken positive step in proposing the formation of the Financial Investigative Authority (FIA), which is expected to be a separate agency staffed from members seconded from the Police FINU, customs, tax, and civil service and the AGC. As part of the FIA, there will be a need for some ad hoc powers to bring in expertise, such as forensic accounting, as necessary for deeper investigations. The proposal envisages that FIA will be independently funded and internally controlled, but with a steering committee from the parent agencies and the governor's office. It is expected that the FIA will have powers of the police and customs, and other powers as may be necessary. These powers should be expressly delineated in the enabling legislation forming the FIA. Although the proposed FIA will be a hybrid of financial intelligence analysis and investigative functions, there should be clear procedures for distinguishing the financial intelligence analysis and the transformation of the intelligence into investigative evidence that is admissible in court proceedings. At minimum, the FIA's internal procedures should have provisions to reduce potential conflicts of interest among the various bodies. An important dimension is the autonomy and integrity of the new unit. The relationship between the RA and the FIA must be clearly regulated, taking into account their partially different tasks and the need for limiting access to certain types of agency-specific information.

134. International cooperation and provision of mutual legal assistance appear to function effectively. The BVI authorities have taken the need for provision of mutual legal assistance seriously and have implemented a number of efforts for enhanced international law enforcement cooperation. The BVI laws allow for broad exchanges of information, both for investigations and prosecutions, and for regulatory matters, although requiring dual criminality for the provision of evidence and records. The PCCA specifically provides for the enforcement of external confiscation orders for money laundering. Amendments to mutual legal assistance laws are contemplated, in order to widen the scope of assistance and to authorize the police to interrogate witnesses directly under a mutual legal assistance request. There are a substantial number of requests for assistance from foreign counterparts, as reflected in the available statistics. The statistics compiled are limited to the number of requests in different categories and do not highlight the efforts put into their execution. Many of the requests are handled by the police themselves (company enquiries and checks). Work connected to requests for assistance occupies a major part of the capacity of the Police FIU. The Head and staff of the unit, as well as the AGC, seem very competent in this field and have accumulated considerable experience.

135. There is some strain on the limited number of staff to thoroughly follow up all mutual legal assistance requests in desired detail. The importance of BVI as a financial center strongly suggests that the number of requests for mutual assistance in criminal matters will remain at a high level. As money-laundering operations often will involve several 
jurisdictions, the BVI's role must be considered to be of great significance in the global efforts to fight money laundering and the financing of terrorism.

136. The general framework for AML compliance is contained in the Anti-Money Laundering Code of Practice (AMLCP) and the guidance notes that provide for customer due diligence measures (KYC), record keeping, ongoing monitoring of relationships and transactions, suspicious transaction reporting, and imposing minimum requirements for internal procedures, controls, and audit. The AMLCP specifically incorporates the guidance notes as a requirement for which sanctions apply, thus making these mandatory. The AMLCP and guidance notes provide sufficiently detailed legal requirements and clear instructions for reporting persons to establish effective internal controls and achieve compliance. The AMLCP and guidance notes apply consistently across a broad number of financial intermediaries that includes banks and trust companies, insurance businesses, mutual funds and mutual fund managers, company managers (either registered agents or trust companies), money remitters, and any activities in which money belonging to a client is held or managed by an attorney or accountant. Of ongoing concern is that the Development Bank of the British Virgin Islands is not subject to the AML/CFT requirements in the AMLCP and guidance notes, despite accepting deposits.

137. The FSC is the supervisory authority vested with the responsibility for ensuring adherence to the AMLCP and the guidance notes. The FSC has direct prudential supervisory authority, including assessment of fit-and-proper tests for management of banks and trust companies, insurance, mutual funds and mutual fund managers, and administrators. Currently, money remitters are not licensed and supervised. The FSC has on-site inspection powers as well as broad powers for approval of compliance officers. The FSC is in the process of completing the necessary inspection manuals and procedures needed to exercise its full range of supervisory functions. The Joint Anti-Money Laundering Coordinating Committee (JAMLACC) is the committee charged with promoting AML guidance, training, and education, and is comprised of a cross-section of public and private sectors' representatives. The JAMLACC played a key role in the enactment of the AMLCP and prescribed the guidance notes, but it is not active at present.

138. With respect to implementation, the most important tool, on-site supervision, has not been fully implemented, although there are visits to regulated persons, and questionnaires for compliance are required as part of these visits. The relatively slow implementation is a notable weakness and is evidenced in the minimal implementation of AML/CFT measures in nonprudential sectors of trust and company service providers, money remitters, lawyers, and accountants. Even in the prudential sectors of banking, insurance, and mutual funds and mutual fund managers, transaction testing and file verification are not fully implemented. The progress in implementation in the trust and company service provider sector, and for attorneys and accountants, is a concern that requires accelerated action by the FSC. The failure to address money remitters in the supervisory measures is also of serious concern. The FSC recognizes these issues and is actively engaged in various projects that are intended to address the identified weaknesses and gaps. 
139. Nevertheless, in their outreach efforts, the FSC has found a high-level awareness and desire to achieve compliance across sectors, and that industries have been responsive to adopting internal controls policies and procedures, as well as adhering to KYC requirements. Of continuing concern is the reliance on eligible introducers to conduct KYC on behalf of BVI financial intermediaries. Verification is needed to ascertain whether the supervisory controls in place are sufficient to test whether the eligible introducers are meeting the statutory requirements to qualify under the AMLCP for performance $\mathrm{KYC}$ requirements. Money remitters are not subject to licensing and supervision, so implementation through supervisory measures is not completed as to these entities.

140. Implementation must be completed and on-site inspections should be regularly used to verify the compliance programs for AML/CFT. Specific transaction testing should be implemented as part of both on-site inspection and as a requirement for internal audit testing by reporting persons. Supervisory controls should pay particular attention to adherence to KYC requirements by company service providers.

\section{Summary assessment against the FATF Recommendations}

141. BVI has moved forward with a legal framework that is consistent with the FATF 40+8 Recommendations; however, implementation has been slower, particularly in the supervisory area. 
Table 5. Recommendations and Actions

\begin{tabular}{|c|c|}
\hline Reference FATF Recommendation & Recommended Action \\
\hline \multicolumn{2}{|l|}{40 Recommendations for AML } \\
\hline Provisional measures and confiscation (FATF 7) & $\begin{array}{l}\text { The PCCA or other legislation should provide for a specific } \\
\text { forfeiture provision that allows for forfeiture of all property } \\
\text { laundered and instrumentalities associated with an ML offence. } \\
\text { Authorities should consider statutory authority for administrative } \\
\text { bodies, such as the FSC or the RA, to identify or freeze assets that } \\
\text { are suspected of being ML or FT assets for a short period a time. }\end{array}$ \\
\hline $\begin{array}{l}\text { General role of financial system in combating ML } \\
\text { (FATF 8-9) }\end{array}$ & $\begin{array}{l}\text { Regulation of independent money remitters should be completed, } \\
\text { including licensing and supervision procedures. }\end{array}$ \\
\hline $\begin{array}{l}\text { Customer identification and record-keeping rules } \\
\text { (FATF 10-13) }\end{array}$ & $\begin{array}{l}\text { It is advisable that the FSC enhance on-site inspections, } \\
\text { particularly in mutual fund, insurance, and banking to include file } \\
\text { sampling for KYC and beneficial owner information. Inspection } \\
\text { procedures and manuals should be completed. Special attention } \\
\text { should be given to assessing whether beneficial ownership } \\
\text { information is regularly obtained and sufficient, particularly when } \\
\text { due diligence is being carried out by eligible introducers. }\end{array}$ \\
\hline \multirow[t]{2}{*}{$\begin{array}{l}\text { Increased diligence of financial institutions (FATF } \\
\text { 14-19) }\end{array}$} & $\begin{array}{l}\text { Consideration should be given to enacting a mandatory suspicious } \\
\text { transaction reporting system. }\end{array}$ \\
\hline & $\begin{array}{l}\text { Specific authority of the RA or FINU to obtain additional } \\
\text { information after an STR is filed should be considered. } \\
\text { Alternatively, consideration should be given to empowering the } \\
\text { FSC to obtain additional information in support of STRs. }\end{array}$ \\
\hline $\begin{array}{l}\text { Measures to cope with countries with insufficient } \\
\text { AML measures (FATF 20-21) }\end{array}$ & $\begin{array}{l}\text { The FSC should issue specific guidelines on establishing } \\
\text { relationships or transactions with countries with insufficient AML } \\
\text { measures. }\end{array}$ \\
\hline $\begin{array}{l}\text { Implementation \& role of regulatory and other } \\
\text { administrative authorities (FATF 26-29) }\end{array}$ & Implementation of on-site inspections is required immediately. \\
\hline \multirow[t]{2}{*}{$\begin{array}{l}\text { Administrative Cooperation - Exchange of } \\
\text { information relating to suspicious transactions (FATF } \\
\text { 32) }\end{array}$} & $\begin{array}{l}\text { The authority of the RA or the Police FIU to obtain additional } \\
\text { information from financial institutions in follow-up to STRs } \\
\text { should be specified by law or regulation. }\end{array}$ \\
\hline & $\begin{array}{l}\text { There should be clear procedures for distinguishing the financial } \\
\text { intelligence analysis and the transformation of the intelligence into } \\
\text { investigative evidence that is admissible in court proceedings. }\end{array}$ \\
\hline Enforcement powers and sanctions & $\begin{array}{l}\text { Vacancies for positions with the FSC's Division for Legal and } \\
\text { Enforcement should be filled as soon as reasonably practicable. } \\
\text { Compliance levels within the financial sector cannot be properly } \\
\text { monitored or ascertained until staffing is complete and staff is } \\
\text { properly trained. Staffing therefore needs to be more robust to } \\
\text { effectively implement the requirements of the AML/CFT legal } \\
\text { framework. }\end{array}$ \\
\hline Integrity standards & $\begin{array}{l}\text { The fit-and-proper tests should be applied to mutual funds and } \\
\text { mutual fund managers, and to money remitters, when the specific } \\
\text { sectoral acts are amended/enacted. }\end{array}$ \\
\hline
\end{tabular}




\begin{tabular}{|l|l|}
\hline \multicolumn{1}{|c|}{ Reference FATF Recommendation } & \multicolumn{1}{c|}{ Recommended Action } \\
\hline Suspicious transaction reporting & $\begin{array}{l}\text { Consideration should be given to enacting a mandatory suspicious } \\
\text { transaction reporting system. }\end{array}$ \\
$\begin{array}{l}\text { The RA should keep statistics on STRs received, STRs analyzed } \\
\text { and disseminated, STRs resulting in investigation, and prosecution } \\
\text { or convictions. }\end{array}$ \\
\hline
\end{tabular}

\section{Authorities' response}

142. With reference to the recommended actions mentioned above, it is intended that they will to a large extent be fulfilled upon the enactment/amendment of key legislation as described below.

143. Provisional measures and confiscation. The Proceeds of Criminal Conduct Act (PCCA) (1997) provides generally for the making of confiscation orders in relation to property that is income or profit derived from the proceeds of crime. There is no provision contemplated for the specific forfeiture of instrumentalities associated with a money laundering offence within the intended amendment to the PCCA.

144. The Financial Investigation Agency Act 2004 does in fact provide for the Reporting Authority to identify and freeze assets for a short period of time (five days). The section, $4(2)(c)$, contemplates such action when it is as a result of a request from a foreign investigation agency or law enforcement authority including the Commissioner of Police.

145. General role of financial system in combating money laundering. The proposed Money Services Act which would provide inter alia for the regulation, supervision and licensing along with the application of the relevant fit and proper tests should be enacted within the second quarter of 2004.

146. Increased diligence of financial institutions. There are no specific statutory provisions which provide for a system of mandatory statutory reporting. The PCCA provides for a voluntary system. The recently enacted FIA Act however specifically provides (Section 20 ) that the FSC shall issue guidelines governing suspicious transaction reporting procedures.

147. Section 4 (2) (b) of the FIA Act allows the agency to direct any person to refrain from completing a transaction for a period of seventy- two hours subsequent to the receipt of a disclosure. Whilst this section does not specifically state that additional information could be obtained, the wide powers of the Agency generally and the import of the subsection allow for further and more detailed information to be obtained.

148. Administrative cooperation-exchange of information relating to suspicious transactions. FIA Act Section 4 (2) (d) allows for the Agency to require the production of any information that it considers relevant to the performance of its functions. This would 
necessarily include the obtaining of additional information from financial institutions as a follow up to STRs.

149. The FIA Act does not establish procedures for distinguishing between financial intelligence analysis and the transmittal of the intelligence into investigative evidence but such guidelines do in fact exist in practice and section 5 of the FIA Act provides for the issuing of directions as to the policy to be followed by the Agency in the performance of its functions.

150. Integrity standards. The Mutual Funds (Amendment) Act has been drafted and has a time frame for enactment within the first quarter of 2004 and would provide for the relevant fit and proper tests to be applied.

\section{Regulatory Arrangements of Particular Concern in the OFC Context}

\section{A. Oversight of Companies and Trusts Service Providers (CSP)}

\section{IBCs}

151. The regime for registering and maintaining IBCs in the territory meets and in many ways exceeds best practices, largely because IBCs have to be registered (incorporated) by registered agents who are subject to regulation supervision, including for fit-and-proper standards, by the FSC, and who have due diligence responsibilities under the AMLCP and guidance notes.

152. As with most corporate legislation, there are no stated restrictions on who can beneficially own an IBC. Therefore, an IBC may ultimately be beneficially owned by the beneficiary or beneficiaries of a trust. However, the registered agent is subjected to customer due diligence policies, including identification requirements, under the AMLCP and guidance notes, including identification of beneficial owner.

153. The IBCs are permitted to issue both registered or bearer shares, and the registrar of corporate affairs is not able to give precise figures on how many IBCs do so. While bearer shares are often used for legitimate purposes, such as reducing difficulty and cost in transferring ownership of assets to heirs, and while other jurisdictions (including onshore jurisdictions) use bearer shares for legitimate purposes, the use of bearer shares by criminals to defeat attempts to trace beneficial owners of underlying assets has resulted in considerable criticism of the practice in international fora. For this reason, and after considerable consultation with the industry, amending legislation to the IBCA has been drafted to implement the immobilization of bearer shares. The IBCA will then require that bearer shares be deposited with authorized custodians or with recognized custodians. An amendment to the BTCA to define and establish authorized custodians will consequently have to be undertaken. Recognized custodians are persons not licensed under the BTCA and not resident in the BVI, but based in countries not subject to sanctions by the FATF, and will be subject to prudential and AML regulation. Industry representatives have largely accepted the rationale for introducing the proposed amending legislation, in part because there will be a 
two-year phase-in period for existing companies. While it is not clear exactly how this will improve beneficial ownership identification (shares could still be held in trust by trustees in other jurisdictions not subject to the jurisdiction of the BVI), this requirement appears to satisfy concerns of the FATF and OECD, among others.

154. Under the IBCA, a company must maintain a register of shareholders and may maintain a register of directors. Both the register of shareholders and, if it exists, the registrar of directors must be kept at the registered office. The IBCA allows for directors to be either individuals or companies; it also does not prohibit nominee directors, and the disclosure of information about the true identity of directors to the registrar is optional, although such information must be kept by the registered agent. If information about directors and officers is disclosed to the registrar, it is publicly available. Again, the registered agent has customer due diligence requirements under the AMLCP and guidance notes.

\section{CSPs}

155. All CSPs are subject to regulation and supervision by the FSC. Such oversight largely meets industry best practices as provided in the OGBS Statement of Best Practices. An ongoing project of monitoring and measuring the division's policies against the methodology paper, issued by the OGBS as a follow-up to their statement of best practice, is currently underway in the division.

156. Under the FSC Act, all CSPs are required to appoint a compliance officer, and the FSC has issued guidance notes for compliance officers. In addition, the AMLCP requires all CSPs to appoint a money-laundering reporting officer to receive and take appropriate action on internal suspicious transaction reports. Depending on the size of the CSP, the same person may undertake both these functions.

157. The BVI, via the FSD, began exercising registration and surveillance functions over CSPs since the passage of the BTCA and CMA. Licenses must be renewed every year. In part because of the importance of the IBC sector to the territory, the BVI has made supervision of CSPs a priority. Unlike with respect to banking, insurance, and securities sectors, the FSC has been conducting on-site inspections of the CSPs for the past three years. These inspections have been based on detailed questionnaires and have included information on continuing to meet fit and proper requirements and on the soundness of financial position. A general overview of business has also been included to reach an overall judgment of the general quality and level of service and of the nature of clients. In addition, random checks of files have been undertaken, including to cover requirements under the AMLCP and guidance notes. CSPs covering over 70 percent of total business have been subject to such on-site inspections, which appear to be relatively well conducted.

158. However, particularly in view of very large IBC client base, and in particular the need to assess compliance with the OGBS statement of best practice (including that action can be taken where there is evidence of noncompliance); there is a need to complete inspections of all CSPs, and to draft a regular compliance and on-site inspection program. Also, inspections 
could be more detailed and structured. The staff in the Banking and Fiduciary Services Division of the FSC is well trained and largely abreast of activities in the industry, although there is a general need for additional consultation, but continued training and attendance by staff of international fora to keep abreast of pertinent regulatory developments is a high priority. All staff members have attended the available annual international seminars on company and trust services providers. In this regard, it should also be noted that the FSC is hosting a training seminar for the Caribbean Group of Banking Regulators in 2003. The Divisional budget for 2003 provides for the creation of two further regulators' posts, which will increase the staffing capacity. The Division also runs a summer internship program, which provides exposure and potential employment opportunities to BVI students. Industry representatives have expressed a high regard for the integrity and dedication of the Division in the execution of its statutory duties.

\section{The BVI Association of Registered Agents (ARA), which includes all but one} registered agent (who is expected to join shortly) has issued a Code of Conduct to provide guidance on minimum standards that members should adhere to regarding the relationships with clients, relationships with the BVI authorities, and client acceptance procedures, transfer of clients between registered agents. There is also a peer review and disciplinary system to ensure compliance. Greater contact and consultation by the FSC and the ARA would be helpful. Consideration should be given to engage with the CSP's industry (perhaps through the offices of the ARA) and auditing firms, with a view to introducing a staff secondment program, both to and from the private sector. Although a modus operandi will have to be established to overcome potential conflicts of interest and confidentiality issues, the crosspollination of skills and perspective will deepen the levels of understanding and cooperation, to the benefit of both the regulator and the industry.

160. Although many CSPs have professional indemnity insurance it is not required. Such insurance should be required for licensing.

\section{B. Cross-Border Cooperation and Information Sharing}

161. Section 29 of the FSC Act sets out restrictions on the disclosure of information disclosed to the FSC and its organs, and the circumstance in which these restrictions do not comply. By way of exception to the restrictions on disclosure of information by the FSC, section 29(2)(e) of the FSC Act allows disclosure when it is made for the purpose of enabling or assisting a foreign regulatory authority, including a trading or a security or exchange authority, in a country or jurisdiction approved by the FSC board in discharging duties or exercising powers corresponding to those under the FSC Act, any subsidiary legislation made there under, or any financial services legislation. The authority receiving the disclosure will, however, be required not to transmit any information, document, record, statement or thing disclosed to any other person except with the prior consent of the FSC board.

162. These provisions allow the FSC and its organs to provide assistance to foreign regulatory authorities. As a matter of practice, the FSC makes a distinction between routine informal inquiries and more formal inquiries for legal or regulatory assistance, such as 
requests for information or documents in connection with an investigation into regulatory or criminal violations. The latter are dealt with by the FSC and its organs in accordance with the provisions of the Financial Services (International Cooperation) Act, 2000 ("the FS(IC) Act") which sets out criteria to be taken into account by the FSC in deciding whether to exercise compulsory powers to obtain information or documents not in its possession, in order to provide the assistance requested. The FS(IC) Act also allows the FSC to require the foreign regulator to give certain written undertakings, such as to provide corresponding assistance when requested by a BVI authority, and to make a contribution toward the costs of the exercise of the compulsory powers. In addition, the FS(IC) Act prescribes the procedure for obtaining information by compulsion and provides certain safeguards in connection with the process. The Banking and Fiduciary Services Division, which carries out the day-to-day supervision of CSPs, has received and responded to 43 routine informal inquiries over the last two years form various foreign agencies. Most of the inquiries concerned IBCs, and not the CSPs themselves.

163. The extent to which the BVI director of banking and fiduciary services can hold confidential information received from a regulating authority in another jurisdiction will depend on the law in that jurisdiction and the conditions attached by the foreign regulating authority sharing the information. In addition, section 29(1) of the FSC Act provides that any information and disclosures made to the FSC or any of its organs and representatives in the course of discharging any function or duty or exercising any power under applicable legislation, is privileged and must not be disclosed except as provided in the circumstances enunciated in section 29(2) of the FSC Act.

\section{Authorities' response}

164. The results of the project of monitoring and measuring the FSC's policies against the OGBS Good Practices are that the FSC is compliant in all respect with the exception that the FSC does not require all CSP to have professional indemnity insurance and external auditors do not have the statutory authority and protections necessary to report to the competent authority. The FSC has since drafted a policy guideline requiring all CSP to have professional indemnity insurance and a draft amendment to the BTCA will place statutory responsibilities and provide protection to external auditors when reporting to the FSC. 